$11-2012$

\title{
Influence of natural and novel organic carbon sources on denitrification in forest, degraded urban, and restored streams
}

TA Newcomer

SS Kaushal

PM Mayer

AR Shields

Elizabeth A. Canuel

Virginia Institute of Marine Science

See next page for additional authors

Follow this and additional works at: https://scholarworks.wm.edu/vimsarticles

Part of the Environmental Sciences Commons

\section{Recommended Citation}

Newcomer, TA; Kaushal, SS; Mayer, PM; Shields, AR; Canuel, Elizabeth A.; and al, et, "Influence of natural and novel organic carbon sources on denitrification in forest, degraded urban, and restored streams" (2012). VIMS Articles. 1712.

https://scholarworks.wm.edu/vimsarticles/1712

This Article is brought to you for free and open access by the Virginia Institute of Marine Science at W\&M ScholarWorks. It has been accepted for inclusion in VIMS Articles by an authorized administrator of W\&M ScholarWorks. For more information, please contact scholarworks@wm.edu. 


\section{Authors}

TA Newcomer, SS Kaushal, PM Mayer, AR Shields, Elizabeth A. Canuel, and et al 


\title{
Influence of natural and novel organic carbon sources on denitrification in forest, degraded urban, and restored streams
}

\author{
Tamara A. Newcomer,${ }^{1,7}$ Sujay S. Kaushal,,${ }^{1}$ Paul M. Mayer, ${ }^{2}$ Amy R. Shields, ${ }^{3}$ Elizabeth A. Canuel, ${ }^{4}$ \\ Peter M. Groffman, ${ }^{5}$ And Arthur J. Gold ${ }^{6}$ \\ ${ }^{1}$ University of Maryland, Department of Geology and Earth System Science Interdisciplinary Center, 5825 University Research Court, \\ Room 4048, College Park, Maryland 20740 USA \\ ${ }^{2}$ US Environmental Protection Agency, Office of Research and Development, National Risk Management Research Lab, Ada, \\ Oklahoma 74820 USA \\ ${ }^{3}$ U.S. Environmental Protection Agency, Region 7, Water, Wetlands, and Pesticides Division, Water Quality Management Branch, \\ 901 North 5th Street, Kansas City, Kansas 66101 USA \\ ${ }^{4}$ Virginia Institute of Marine Science, College of William and Mary, P.O. Box 1346, Gloucester Point, Virginia 23062 USA \\ ${ }^{5}$ Cary Institute of Ecosystem Studies, Box AB, Millbrook, New York 12545 USA \\ ${ }^{6}$ University of Rhode Island, Department of Natural Resources Science, Coastal Institute in Kingston 110, Kingston, \\ Rhode Island 02881 USA
}

\begin{abstract}
Organic carbon is important in regulating ecosystem function, and its source and abundance may be altered by urbanization. We investigated shifts in organic carbon quantity and quality associated with urbanization and ecosystem restoration, and its potential effects on denitrification at the riparian-stream interface. Field measurements of streamwater chemistry, organic carbon characterization, and laboratory-based denitrification experiments were completed at two forested, two restored, and two unrestored urban streams at the Baltimore Long-Term Ecological Research site, Maryland, USA. Dissolved organic carbon (DOC) and nitrate loads increased with runoff according to a power-law function that varied across sites. Stable isotopes and molar $\mathrm{C}: \mathrm{N}$ ratios suggested that stream particulate organic matter (POM) was a mixture of periphyton, leaves, and grass that varied across site types. Stable-isotope signatures and lipid biomarker analyses of sediments showed that terrestrial organic carbon sources in streams varied as a result of riparian vegetation. Laboratory experiments indicated that organic carbon amendments significantly increased rates of denitrification $\left(35.1 \pm 9.4 \mathrm{ng} \mathrm{N} \cdot[\mathrm{g} \text { dry sediment }]^{-1} \cdot \mathrm{h}^{-1}\right.$; mean $\left.\pm \mathrm{SE}\right)$ more than nitrate amendments $\left(10.4 \pm 4.0 \mathrm{ng} \mathrm{N} \cdot[\mathrm{g} \text { dry sediment }]^{-1} \cdot \mathrm{h}^{-1}\right)$ across streamflow conditions and sites. Denitrification experiments with naturally occurring carbon sources showed that denitrification was significantly higher with grass clippings from home lawns $(1244 \pm 331 \mathrm{ng} \mathrm{N} \cdot \mathrm{g}$ dry sediment $\mathrm{t}^{-1} \cdot \mathrm{h}^{-1}$ ), and overall unrestored urban sites showed significantly higher denitrification rates than restored and forest sites. We found that urbanization influences organic carbon sources and quality in streams, which can have substantial downstream impacts on ecosystem services such as denitrification.

Key words: Baltimore County, Maryland, USA; C:N ratio; denitrification; dissolved organic carbon; grass clippings; lipid biomarkers; nitrogen; organic carbon; stable isotopes; stream restoration; urbanization; urban stream.
\end{abstract}

\section{INTRODUCTION}

Organic carbon plays a key role in regulating ecosystem functions (Fisher and Likens 1973, Vannote et al. 1980). In streams and rivers, dissolved organic carbon (DOC) serves as an energy source for microorganisms and influences nutrient cycling (Edwards and Meyer 1987, McDowell and Likens 1988, Bernhardt et al. 2002), forms complexes with metals (Perdue et al. 1976), absorbs ultraviolet light (Frost et al. 2005), and can stimulate production of disinfection by-products in drinking water during chlorination (Krasner et al. 1989,

Manuscript received 19 March 2012; accepted 30 March 2012. Corresponding Editor: W. V. Sobczak.

${ }^{7}$ E-mail: newcomer@umd.edu
Kraus et al. 2008). Availability of dissolved and particulate organic carbon can limit denitrification, a microbial process critical to maintaining water quality (Sobczak et al. 2003, Mayer et al. 2010).

Many streams and rivers in the United States have elevated concentrations of nitrogen (Carpenter et al. 1998, Howarth et al. 2006). The Chesapeake Bay watershed has elevated $\mathrm{NO}_{3}{ }^{-}$concentrations in many streams and rivers because of agricultural and urban land use and fossil fuel combustion (Boesch et al. 2001, Kemp et al. 2005, Kaushal et al. 2008a). We need to enhance $\mathrm{N}$ management within watersheds to reduce downstream delivery to sensitive coastal waters (Boesch et al. 2001, Kemp et al. 2005, Kaushal et al. 2008b). A key ecosystem service that naturally removes reactive $\mathrm{N}$ is denitrification. Denitrification is an anaerobic micro- 
bial process that typically requires organic carbon as an electron donor (Davidson and Schimel 1995, Groffman et al. 2005, Boyer et al. 2006). The riparian-stream interface, an area where streamwater and groundwater mix, is a "hot spot" for denitrification because it has low levels of dissolved oxygen and high levels of dissolved organic carbon (DOC; e.g., Hedin et al. 1998, Kaushal et al. 2008b, Mayer et al. 2010).

Dissolved organic carbon in streams is a mixture of both recalcitrant and labile fractions, with the labile fraction being important to biogeochemical processes (Findlay and Sinsabaugh 1999, Kaushal and Lewis 2003). Therefore, it is critical to understand which watershed organic carbon sources enter streams and the role that various terrestrial vs. aquatic sources play in influencing denitrification, metabolism, and organic carbon export. In forest ecosystems, riparian vegetation surrounding streams can influence DOC and comprise a substantial proportion of stream organic carbon budgets (Fisher and Likens 1973, McDowell and Likens 1988). The effects of organic carbon sources on ecosystem functions have been quantified for forested streams (McDowell and Likens 1988, McCutchan and Lewis 2002) and agricultural streams (Schaller et al. 2004, Royer and David 2005, Griffiths et al. 2009, Warrner et al. 2009). However, there has been little assessment of the relative importance of sources of natural and anthropogenic organic carbon sources on denitrification in urban streams (Paul and Meyer 2001, Ulseth and Hershey 2005, Paul et al. 2006, Petrone et al. 2011).

Variations in organic carbon from autochthonous (instream) and allochthonous (watershed) sources can be pronounced in urban streams due to flashy hydrology, wastewater inputs, and anthropogenically enhanced sources (Hook and Yeakley 2005, Kaushal et al. 2010, Petrone 2010). Urban watersheds and riparian zones may also have extensively modified vegetation such as home lawns, and this vegetation can have a strong effect on the supply of organic carbon to streams (Ryder and Miller 2005, Pouyat et al. 2009, Kaushal and Belt 2012). Therefore, we need to elucidate how denitrification in sediments may vary in response to stormflow vs. baseflow conditions and in response to changes in the relative importance of terrestrial vs. aquatic sources in urban watersheds.

We investigated the relative importance of different organic carbon sources to denitrification at the riparianstream interface of forested, restored, and unrestored urban streams. During urbanization, large areas that were once forest or agricultural fields are often converted to lawns. In addition, urban stream restoration can influence carbon sources through tree removal and riparian reforestation. Our overall objective was to investigate how urbanization and restoration affect $\mathrm{C}$ and $\mathrm{N}$ delivery to and cycling within streams. Our secondary objective was to explore how uniquely urban organic matter sources such as lawn clippings vs. more natural organic matter sources affect denitrification. Our study objectives were to: (1) determine the influence of land use and restoration status on amounts and sources of organic carbon reaching streams, (2) measure denitrification potential rates associated with baseflow and stormflow conditions, (3) evaluate whether nitrate or carbon amendments stimulated larger denitrification potential rates, and (4) characterize the relative importance of naturally occurring organic carbon sources (leaves, grass, and periphyton) for fostering denitrification across land use and restoration status.

\section{Methods}

Our project design included six Baltimore County, Maryland, USA, streams (two forested, two urban restored, and two unrestored urban). At each site, we monitored discharge and concentrations of nitrate and dissolved organic carbon for two years. We conducted a field survey on how particulate organic matter (POM) and organic carbon sources varied across land use and restoration status by analyzing stable-isotope ratios and molar C: $\mathrm{N}$ ratios. We also used laboratory experiments to measure microbial responses to three organic carbon sources typical of the study systems: grass clippings from home lawns, decomposed leaves taken from debris dams, and periphyton (which was a mixture of filamentous algae and terrestrial detritus). Our laboratory experiments examined changes in denitrification potential rates in sediments from the riparian-stream interface with water taken at baseflow vs. stormflow conditions and in response to different organic carbon sources.

\section{Site description: forest, unrestored urban, and restored streams}

Study sites included six low-order streams (two forested, two restored, and two unrestored urban) in the Baltimore metropolitan area, which is situated in the Piedmont region of Maryland, in the Chesapeake Bay Watershed (Figs. 1 and 2; Appendix B). These sites have been studied as part of the Baltimore Ecosystem Study (BES), one of two urban study sites in the U.S. National Science Foundation Long-Term Ecological Research network (Pickett et al. 2011).

Pond Branch $\left(39^{\circ} 28^{\prime} 49^{\prime \prime} \mathrm{N}, 76^{\circ} 41^{\prime} 16^{\prime \prime} \mathrm{W} ; 32.3 \mathrm{ha}\right)$ is a forested, first-order stream with no impervious surfaces in its watershed. Pond Branch is a tributary of Baisman Run $\left(39^{\circ} 28^{\prime} 45^{\prime \prime} \mathrm{N}, 76^{\circ} 40^{\prime} 42^{\prime \prime} \mathrm{W}\right.$; 381 ha), which is a third-order stream within a watershed that was $66 \%$ forested, $1 \%$ agriculture, $34 \%$ residential with septic systems, and $1 \%$ total impervious surface coverage (Groffman et al. 2004). Discharge in both streams was monitored continuously by the U.S. Geological Survey (USGS) gaging stations.

The two restored streams, Spring Branch $\left(39^{\circ} 26^{\prime} 43.9^{\prime \prime}\right.$ N, 76 $\left.37^{\prime} 12.9^{\prime \prime} \mathrm{W}\right)$ and Minebank Run (39 $24^{\prime} 36^{\prime \prime} \mathrm{N}$, $76^{\circ} 33^{\prime} 23^{\prime \prime} \mathrm{W}$ ), are low-order streams in close proximity to the Loch Raven drinking-water reservoir. Both restorations incorporated a combination of standard 


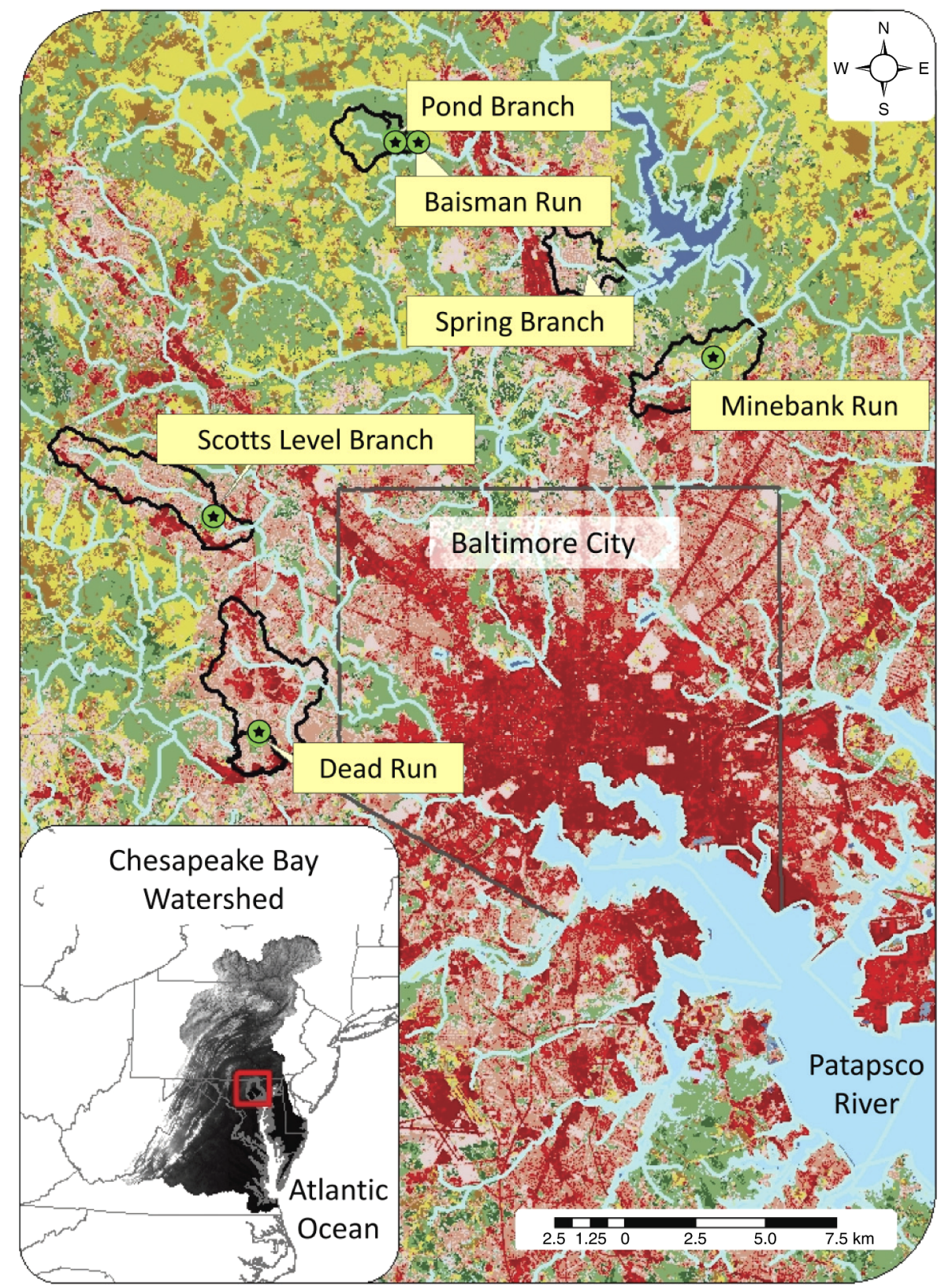

FIG. 1. Land cover map of study sites (outlined with black lines) at the Baltimore Ecosystem Study Long-Term Ecological Research Site, Maryland, USA. Coloration is from the 2001 National Land Cover Database (red indicates urban areas, and green indicates forested areas). Green circles with stars indicate USGS gage locations.

natural channel design techniques (Rosgen 1994) and integrated stormwater management such as hydrologically connected floodplains (Minebank Run; Kaushal et al. 2008b, Klocker et al. 2009) or stormwater management areas including wetlands and ponds below a storm drain outfall (Spring Branch; DEPRM 2008a, b, U.S. EPA 2011). Spring Branch (407 ha) was the first restoration site in Baltimore County, and $3.2 \mathrm{~km}$ of stream length were restored during 1994-1997. Spring Branch was restored by removal of concrete channels, creation of a series of step-pools, tree and shrub plantings for bank stabilization, and creation of multiple-cell stormwater management areas in the headwaters (DEPRM 2008a, b, U.S. EPA 2011). The Spring Branch watershed has a total impervious surface coverage of $18.6 \%$, and land use composition is $91.5 \%$ residential with varying degrees of density (33\% low, $54.8 \%$ medium, and $3.7 \%$ high), $1.7 \%$ institutional (a school), and $6.7 \%$ forest (DEPRM 2008a,b). At Minebank Run (207 ha), $2.4 \mathrm{~km}$ of stream length were restored during 1998-1999 and $2.9 \mathrm{~km}$ were restored from 2004 to 2005 (U.S. EPA 2006). Land use in 
A

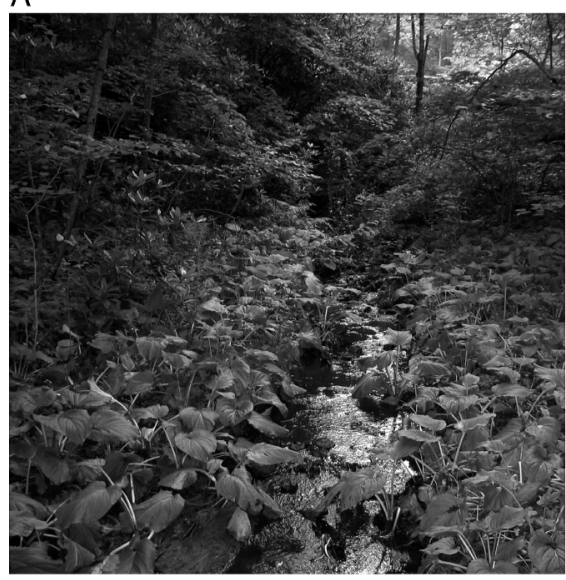

C

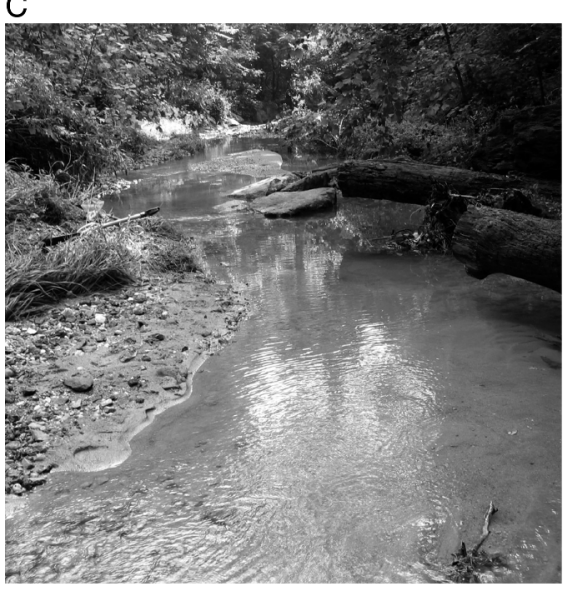

$\mathrm{E}$

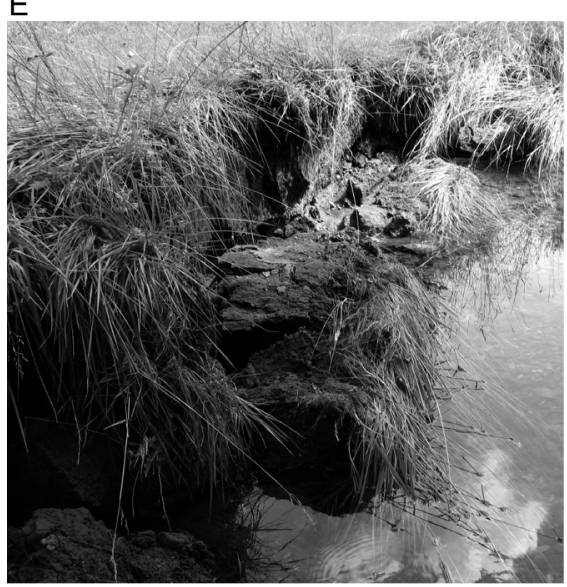

B

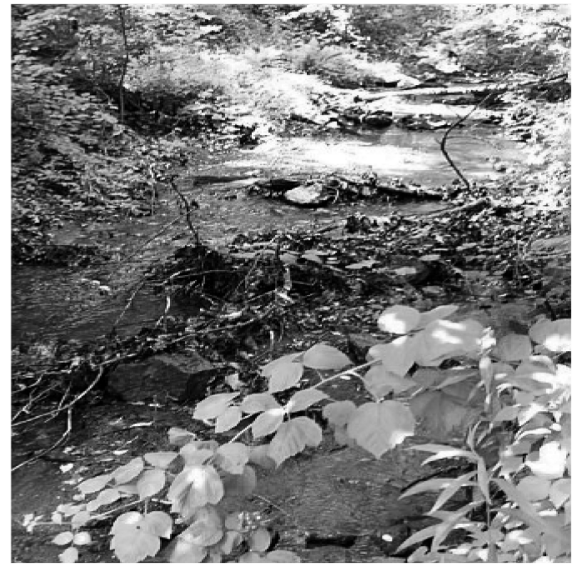

D

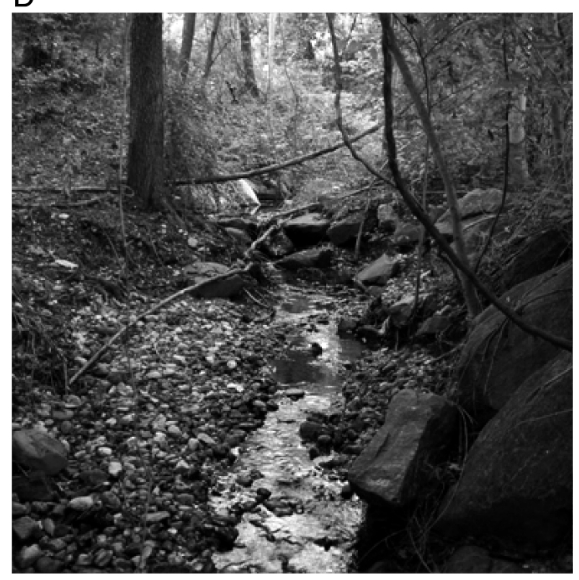

$\mathrm{F}$

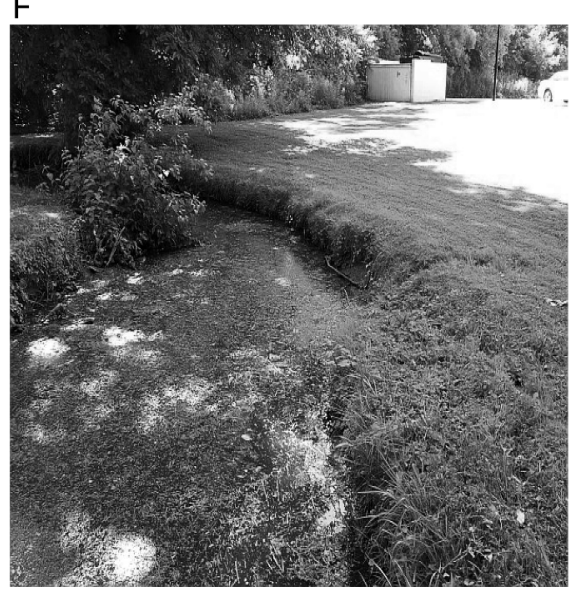

FIG. 2. Photographs showing the (A) forested Pond Branch, (B) forested Baisman Run, (C) restored Minebrook Run, (D) restored Spring Branch, (E) unrestored urban Dead Run, and (F) Scotts Level Branch streams.

Minebank Run is $17 \%$ forest, $2 \%$ agriculture, and $81 \%$ urban/suburban, including 30-35\% total impervious surface coverage (Doheny et al. 2006, 2012). Discharge is continuously monitored at Minebank Run by the USGS.
The two unrestored urban streams are Scotts Levels Branch $\left(39^{\circ} 21^{\prime} 41.8^{\prime \prime} \mathrm{N}, 76^{\circ} 45^{\prime} 42.3^{\prime \prime} \mathrm{W}\right)$ and Dead Run $\left(39^{\circ} 17^{\prime} 45.2^{\prime \prime} \mathrm{N}, 76^{\circ} 44^{\prime} 38.7^{\prime \prime} \mathrm{W}\right)$ on the boundary of urban Baltimore City and suburban Baltimore County. In contrast to the forested streams, Scotts Level Branch 
(836.5 ha) and Dead Run (204.6 ha) have sections where the riparian zone is forested and reaches where lawns are managed to the edge of the stream. Total impervious coverage is $29 \%$ at Scotts Level Branch and $40 \%$ at Dead Run (Ryan et al. 2010). Dead Run is part of the lower Gywnns Falls watershed, which has a land use composition of $2 \%$ agriculture, $14 \%$ forested, $75 \%$ urban, $8 \%$ suburban, and $1 \%$ other (Klocker et al. 2009). Discharge at both streams is monitored continuously by USGS gaging stations.

\section{Temporal changes in $\mathrm{NO}_{3}{ }^{-}$and DOC concentrations and daily fluxes}

From April 2008 to April 2010, we collected monthly surface water samples to characterize temporal changes in nitrate $\left(\mathrm{NO}_{3}{ }^{-}\right)$and DOC concentrations at all six streams over a range of hydrologic conditions. Surface water samples were collected in high-density polyethylene (HDPE) Nalgene bottles that were rinsed five times with sample water prior to sample collection. Samples were filtered within $24 \mathrm{~h}$ using pre-combusted Whatman $0.45-\mu \mathrm{m}$ glass fiber filters $(\mathrm{GF} / \mathrm{F})$ and kept frozen until analysis at the University of Maryland Center for Environmental Science, Chesapeake Biological Laboratory, Solomons, Maryland, USA. Analysis of $\mathrm{NO}_{3}{ }^{-}$was performed with a Dionex ion chromatography system (ICS-1500; Dionex, Sunnyvale, California, USA), and analysis of DOC was performed with a Shimadzu total organic carbon analyzer (TOC-272 V CPH/CPN; Shimadzu, Columbia, Maryland, USA; Kaushal and Lewis 2003, 2005). Daily fluxes were calculated by multiplying concentration $(\mathrm{mg} / \mathrm{L})$ by stream flow $(\mathrm{L} / \mathrm{d})$ to get mass transport per day. We used mean daily stream flow recorded at five sites with USGS gages (forested Pond Branch is gage 01583570, forested Baisman Run is 01583580, unrestored urban Scotts Level Branch is 01589290, unrestored urban Dead Run is 01589312, and restored Minebank Run is 0158397967) and measured instantaneous stream flow at the restored Spring Branch site with a Marsh McBirney 2000 (Hach Company, Loveland, Colorado, USA) velocity meter.

\section{Organic matter sources: $C: N$ ratios, $\delta^{15} N$ and $\delta^{13} C$} isotopic analysis, lipid biomarkers

We analyzed $\delta^{15} \mathrm{~N}$ and $\delta^{13} \mathrm{C}$ isotopic ratios and molar $\mathrm{C}: \mathrm{N}$ ratios on triplicate samples of sediment, grass, periphyton, leaves, and POM that we collected at two locations at five streams: forested Pond Branch and Baisman Run, restored Spring Branch and Minebank Run, and unrestored urban Dead Run (unrestored urban Scotts Level Branch was omitted because of time and cost constraints). Particulate organic carbon (POC) and particulate nitrogen $(\mathrm{PN})$ samples were collected by filtering $750-1000 \mathrm{~mL}$ of streamwater (collected at the surface using 2-L amber HDPE bottles) through a 125$\mu \mathrm{m}$ sieve followed by filtering onto a pre-combusted Whatman $\mathrm{GF} / \mathrm{F}$ filter $\left(0.8 \mu \mathrm{m} ; 25 \mathrm{~mm}\right.$ diameter; $500^{\circ} \mathrm{C}$ for $2 \mathrm{~h}$ ). The POM filters were rinsed with $10 \% \mathrm{HCl}$ to remove carbonates, and then rinsed with deionized water. The filters were placed in combusted foil and frozen at $-80^{\circ} \mathrm{C}$ until subsequent analysis. Sediments were collected at the riparian-stream interface from a depth of $\sim 0.5$ $\mathrm{m}$ below the baseflow water surface elevation using a soil auger at each stream. Samples were placed in washed, combusted $\left(450^{\circ} \mathrm{C}, 4.5 \mathrm{~h}\right) 0.12-\mathrm{L}$ (4-oz) Qorpak jars and put on dry ice in the field until returned to the laboratory and stored at $-80^{\circ} \mathrm{C}$. Organic carbon sources (grass, leaves, and periphyton) were collected at each site and were placed into the Alconox-washed, combusted $\left(450^{\circ} \mathrm{C}\right.$, 4.5 hours) 4-oz Qorpak jars and put on dry ice in the field until returned to the laboratory and stored at $-80^{\circ} \mathrm{C}$. Grass samples were typically cut from as near the stream as possible, leaves were collected from debris dams within the stream channel, and periphyton samples were collected from within the stream. Before final analysis, filters, sediment, and vegetation samples were rinsed, dried, milled, and acidified according to protocols of the Stable Isotope Facility, University of California, Davis, California, USA (UC Davis; details available online). ${ }^{8}$ Samples were shipped to UC Davis for analysis on a PDZ Europa ANCA-GSL elemental analyzer interfaced to a PDZ Europa 20-20 isotope ratio mass spectrometer (Sercon, Cheshire, UK). The stable-isotope ratios ${ }^{13} \mathrm{C}:{ }^{12} \mathrm{C}$ and ${ }^{15} \mathrm{~N}:{ }^{14} \mathrm{~N}$ are reported in delta $(\delta)$ units as per-mil difference between the ratio of the sample to the standard (Pee Dee belemnite [PDB] and air, respectively).

Lipid biomarker analyses were conducted to further investigate the sources of organic carbon in stream sediments. We used lipid biomarkers to examine contributions from terrestrial (percentage of long-chain fatty acids, percentage of long-chain alcohols, and percentage of plant sterols) and aquatic-source indicators (percentage of short-chain alcohols and percentage of diatom sterols). Two sediment samples were collected from each of three sites: forested Pond Branch, restored Spring Branch, and restored Minebank Run during May and June 2008. We were unable to conduct lipid biomarker analyses at all sites due to cost restraints. Sediment samples were extracted in a 2:1 solution of $\mathrm{CH}_{2} \mathrm{Cl}_{2}: \mathrm{CH}_{3} \mathrm{OH}$ (DCM:MeOH) using an accelerated solvent extraction-200 (ASE; Dionex) at $80^{\circ} \mathrm{C}$ and 12.4 $\mathrm{MPa}(1800 \mathrm{psi} ; 2 \times 10 \mathrm{~min}$ cycles $)$ following a modification of the Bligh and Dyer (1959) method (Waterson and Canuel 2008). Frozen sediments were thawed, homogenized, and dried with hydromatrix prior to extraction. Surrogate standards including a fatty acid methyl ester (FAME), methyl nonadecanoate $\left(\mathrm{C}_{19}\right.$ FAME), nonadecanol, a wax ester (myristyl arachidate) that yielded a $\mathrm{C}_{14}$ alcohol and a $\mathrm{C}_{20}$ FAME following saponification, and androstanol were added to each sample prior to extraction. Extracts were partitioned into two phases, and the lower organic phase collected. The aqueous phase was back-extracted into hexane and

${ }^{8} \mathrm{http}: / /$ stableisotopefacility.ucdavis.edu 
the combined organic phases placed over anhydrous $\mathrm{Na}_{2} \mathrm{SO}_{4}$ overnight to reduce traces of $\mathrm{H}_{2} \mathrm{O}$. The samples were concentrated to $1 \mathrm{~mL}$ using turbo-evaporation (Zymark Turbo Vap 500; Caliper Technologies, Hopkinton, Maryland, USA). The mass of each total lipid extract (TLE) was determined gravimetrically using aliquots representing $\sim 10 \%$ of the TLE. A portion of the extract was saponified using $1 \mathrm{~mol} / \mathrm{L} \mathrm{KOH}$ in aqueous methanol $\left(110^{\circ} \mathrm{C}\right.$ for $\left.2 \mathrm{~h}\right)$. Neutral and acidic lipids were extracted into hexane from the saponified sample following Canuel and Martens (1993). Fatty acids were converted to methyl esters using $\mathrm{BF}_{3}-\mathrm{MeOH}$. Both fatty acids (as methyl esters) and neutral lipids were separated from other lipid classes by silica gel chromatography following Canuel and Martens (1993). Sterols were derivatized to trimethylsilyl (TMS) ethers using BSTFA and acetonitrile and heating at $70^{\circ} \mathrm{C}$ for 30 min. Fatty acids (as methyl esters) and alcohols/sterols (as TMS ethers) were analyzed using gas chromatography (GC; Hewlett Packard 5890 Series II Plus, Palo Alto, California, USA) with flame ionization detection using a $40 \mathrm{~m} \times 0.18 \mathrm{~mm}$ DB5 column (J\&W Scientific; Agilent Technologies, Santa Clara, California, USA). Peak areas were quantified relative to internal standards: $\mathrm{C}_{21}$ FAME was used for fatty acids and $5(\alpha)-\mathrm{H}-$ cholestane for alcohols/sterols. A GC interfaced to a mass selective detector (Hewlett Packard 6890 GCMSD) operated in electron impact mode was used to verify the identification of individual compounds using similar conditions as for GC analysis.

\section{Experimental design for denitrification experiments}

Denitrification experiments were related to three of our four overall study objectives: (1) evaluate whether nitrate or carbon availability produced a greater denitrification potential response, (2) measure the denitrification potential rates associated with baseflow and stormflow, and (3) characterize the relative importance of naturally occurring organic carbon sources to denitrification across land use and restoration status.

We conducted two types of denitrification experiments. The first involved amending sediment and streamwater with glucose or nitrate to determine how denitrification potential rates were affected by $\mathrm{N}$ and $\mathrm{C}$ availability, hydrologic conditions (stormflow vs. baseflow), and restoration status. The second experiment involved incubating sediment and streamwater with naturally occurring organic carbon sources (grass, periphyton, or leaves) to assess their differential impacts on denitrification. The first experiment had a factorial design with three factors: (1) site type (forested, restored, and unrestored urban), (2) streamwater type (collected during baseflow and stormflow conditions), and (3) amendment type (glucose and nitrate). The second experiment had a factorial design with two factors: (1) site type (forested, restored, and unrestored urban) and (2) naturally occurring organic carbon source type (control, periphyton, grass, and leaves).

\section{Sample collection for denitrification experiments}

Sediments were collected from each stream at the riparian-stream interface using a gas-powered auger. Sediment samples were taken at two locations at each stream at a distance $\sim 1 \mathrm{~m}$ from the wetted channel perimeter and at a depth of $\sim 0.5 \mathrm{~m}$ below the baseflow water surface elevation. All samples were refrigerated $<2$ weeks before analysis. Organic carbon sources (grass, periphyton, and leaves) were collected from the riparian zone at each site and refrigerated in re-sealable plastic bags for $<2$ weeks before the experiments. Grass samples were typically cut from as near the stream as possible, leaves were collected from debris dams within the stream channel, and periphyton samples were collected from within the stream. Leaves, periphyton, and grass clippings were rinsed in the laboratory with deionized water to remove possible silt or debris. In a few cases, periphyton or grass were not available from a particular study site, and were used from a nearby site or location. Samples were collected during June 2006. We collected stormflow streamwater during a storm on 25 June 2006 and baseflow streamwater four days later. Organic carbon sources change over time, so these experiments should be considered a snapshot of field conditions at the time of collection.

\section{Denitrification potential rate methodology}

Denitrification enzyme activity assays are widely used to compare sites and treatments (Smith and Tiedje 1979, Groffman et al. 1999, 2005, 2006, Roach and Grimm 2011). Briefly, we amended $5.0 \mathrm{~g}$ of sediment and $10 \mathrm{~mL}$ of streamwater with a media made of organic carbon (glucose), nitrate $\left(\mathrm{KNO}_{3}{ }^{-}\right)$, and chloramphenicol (Groffman et al. 1999). We added enough organic carbon and nitrate to ensure denitrification was not limited and added chloramphenicol to block the production of new enzymes during incubation. This mixture was sealed in 125-mL Erlenmeyer flasks using rubber stoppers, and the headspace was evacuated and replaced with $\mathrm{N}_{2}$ gas. Acetylene was added to each flask to block the final step of denitrification, the transformation of $\mathrm{N}_{2} \mathrm{O}$ to $\mathrm{N}_{2}$. Gas samples were taken at $30 \mathrm{~min}$ and $90 \mathrm{~min}$. Samples were stored in evacuated glass vials, and $\mathrm{N}_{2} \mathrm{O}$ concentrations were analyzed by gas chromatography using a Shimadzu GC 14 gas chromatograph outfitted with an electron capture detector at the Cary Institute for Ecosystem Studies, Millbrook, New York, USA.

\section{Denitrification experiment 1: glucose vs. nitrate amendment}

In this first experiment, we conducted denitrification enzyme assays where we amended sediments with either glucose or nitrate. For glucose amendments, glucose concentrations were increased by $500 \mathrm{mg} / \mathrm{L}$ so that we could measure denitrification potential rates associated with ambient nitrate in streamwater samples collected under different hydrologic conditions (baseflow or 

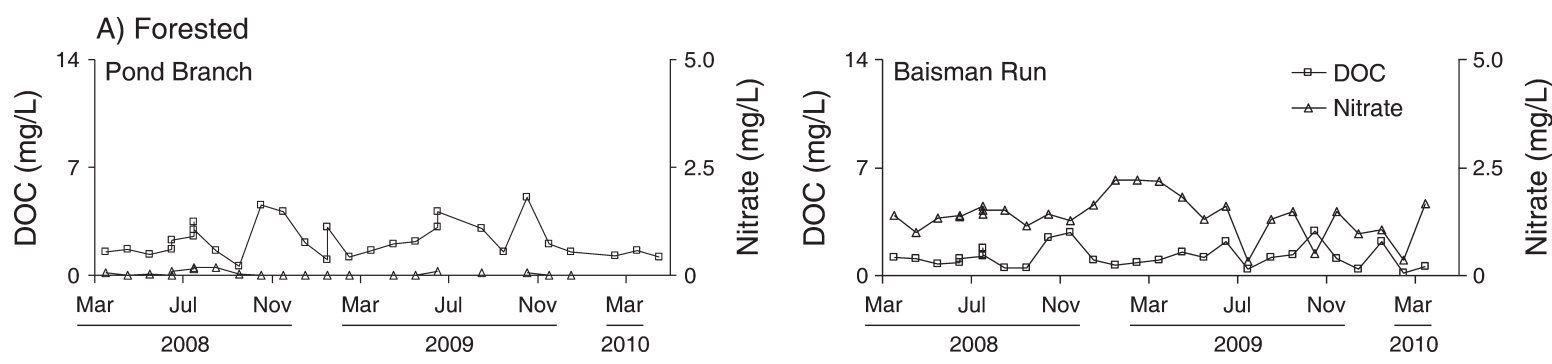

\section{B) Restored}
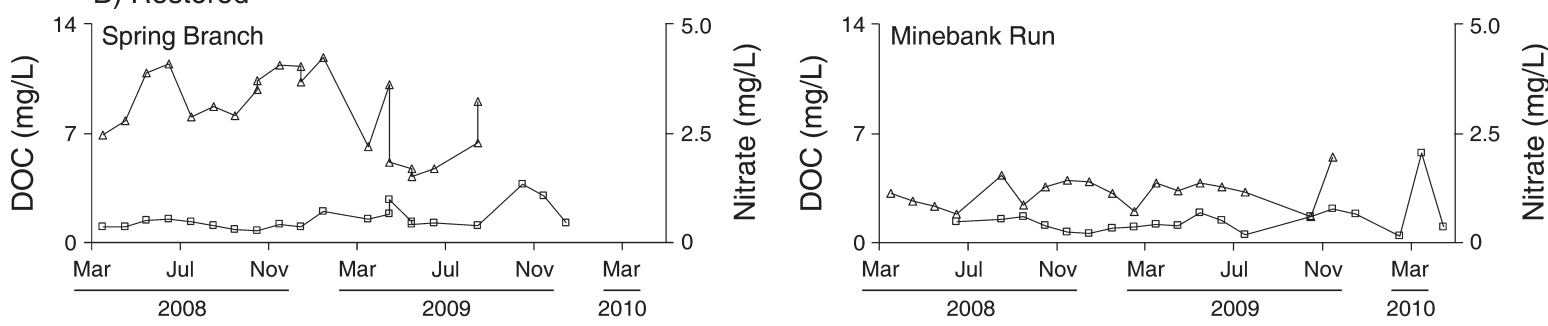

C) Unrestored urban
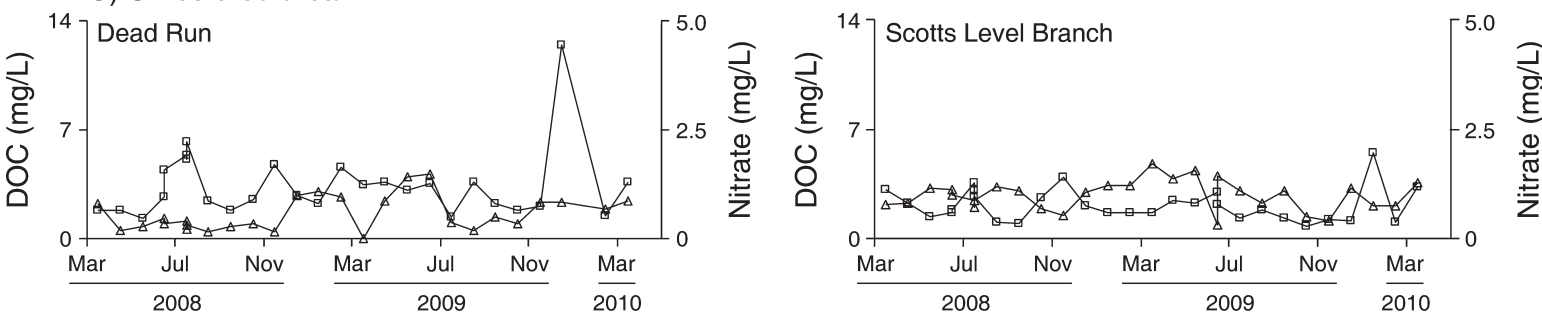

FIG. 3. Monthly dissolved organic carbon (DOC) and nitrate concentrations from (A) forested, (B) restored, and (C) unrestored urban watersheds.

stormflow) across study sites. For the nitrate amendment experiment, we increased the $\mathrm{KNO}_{3}$ concentration by $720 \mathrm{mg} / \mathrm{L}$ so that we could measure denitrification potential rates associated with ambient organic carbon. Our experimental design for comparing glucose, nitrate, and stormwater included 96 samples $(6$ stream sites $\times 2$ locations per stream $\times 2$ amendment types [organic carbon and nitrate] $\times 2$ hydrologic conditions [baseflow and stormflow] $\times 2$ duplicates).

\section{Denitrification experiment 2: effects of naturally occurring carbon sources on denitrification}

A second denitrification enzyme activity experiment was conducted to investigate how different naturally occurring organic carbon sources affected denitrification potential rates. This experiment used media that included nitrate but omitted glucose to induce carbon limitation. The dry mass equivalent of $0.2 \mathrm{~g}$ of local organic carbon (grass, periphyton, or leaves) was made into a slurry in a blender and added to the incubations in place of glucose as an organic carbon source. Slurries were incubated with sediment, streamwater, and media in 200 -mL (half-pint) Mason jars. Controls contained only sediment, streamwater, and media. Our experimental design for comparing the effects of naturally occurring organic carbon sources on denitrification rates across streams included 96 samples $(6$ streams $\times 2$ locations per stream $\times 4$ organic carbon sources [control, grass, periphyton, or leaves] $\times 2$ duplicates).

\section{Statistical analysis}

Statistical analyses were performed using SAS Analyst (SAS Institute 2003). Differences in streamwater chemistry, denitrification potential rates, and $\mathrm{C}: \mathrm{N}$ ratios, and lipid biomarkers were evaluated using an analysis of variance (ANOVA) followed by Tukey's test with a significance level $(\alpha)$ of 0.05 . We evaluated differences in denitrification potential rates across site type (forest, restored, and unrestored urban), organic carbon source (periphyton, leaves, and grass), and flow conditions (baseflow streamwater and stormflow streamwater).

\section{RESUlts}

\section{Concentrations and fluxes of $\mathrm{NO}_{3}{ }^{-}$and $\mathrm{DOC}$}

Pond Branch (forested) had significantly lower and Spring Branch (restored) had significantly higher mean nitrate- $\mathrm{N}$ concentrations than other sites $\left(F_{5,150}=94.33\right.$, $N=159, P<0.01$; Fig. 3, Table 1). The low-density residential forested site, Baisman Run, had significantly lower and Dead Run (unrestored urban) had signifi- 
TABLE 1. Dissolved organic carbon (DOC) and nitrate concentration $(\mathrm{mg} / \mathrm{L})$ in forested, restored, and unrestored urban Baltimore, Maryland, USA, streams from April 2008 to April 2010.

\begin{tabular}{|c|c|c|c|c|c|}
\hline $\begin{array}{l}\text { Restoration status } \\
\text { and stream }\end{array}$ & Analysis & $\begin{array}{c}\text { Tukey } \\
\text { comparison }\end{array}$ & Mean $\pm \mathrm{SE}$ & Range & $\begin{array}{l}\text { Sample } \\
\text { size }(N)\end{array}$ \\
\hline \multicolumn{6}{|l|}{ Forested } \\
\hline \multirow[t]{2}{*}{ Pond Branch } & DOC & a & $2.13 \pm 0.14$ & $0.62-5.07$ & 47 \\
\hline & $\mathrm{NO}_{3}{ }^{-}$ & A & $0.045 \pm 0.010$ & $0.001-0.188$ & 31 \\
\hline \multirow[t]{2}{*}{ Baisman Run } & DOC & $\mathrm{b}$ & $1.23 \pm 0.13$ & $0.20-2.87$ & 28 \\
\hline & $\mathrm{NO}_{3}{ }^{-}$ & B & $1.374 \pm 0.089$ & $0.323-2.215$ & 28 \\
\hline \multicolumn{6}{|l|}{ Restored } \\
\hline \multirow[t]{2}{*}{ Spring Branch } & DOC & $a, b, c$ & $1.50 \pm 0.16$ & $0.71-3.74$ & 25 \\
\hline & $\mathrm{NO}_{3}{ }^{-}$ & & $2.898 \pm 0.222$ & $0.704-4.218$ & 22 \\
\hline \multirow{2}{*}{ Minebank Run } & DOC & $\mathrm{b}, \mathrm{c}$ & $1.38 \pm 0.12$ & $0.40-5.72$ & 48 \\
\hline & $\mathrm{NO}_{3}{ }^{-}$ & $\mathrm{B}, \mathrm{D}$ & $1.083 \pm 0.060$ & $0.470-1.532$ & 22 \\
\hline \multicolumn{6}{|l|}{ Unrestored urban } \\
\hline \multirow{2}{*}{ Dead Run } & DOC & $d$ & $3.42 \pm 0.43$ & $1.33-12.42$ & 27 \\
\hline & $\mathrm{NO}_{3}{ }^{-}$ & E & $0.568 \pm 0.076$ & $0.007-1.469$ & 27 \\
\hline \multirow[t]{2}{*}{ Scotts Level Branch } & DOC & $\mathrm{a}, \mathrm{c}$ & $2.14 \pm 0.20$ & $0.80-5.50$ & 29 \\
\hline & $\mathrm{NO}_{3}^{-}$ & $\mathrm{D}$ & $0.982 \pm 0.062$ & $0.316-1.717$ & 29 \\
\hline
\end{tabular}

Notes: Values are means \pm SE. Letters represent comparisons that are significant $(\alpha=0.05)$ according to Tukey's studentized range (HSD) test; lowercase letters correspond to DOC concentration, and uppercase letters correspond to nitrate concentration.

cantly higher mean DOC concentrations than other sites $\left(F_{5,198}=14.14, N=204, P<0.01\right.$; Fig. 3, Table 1).

At all six streams, the daily loads of DOC and nitrate $(\mathrm{mg} / \mathrm{d})$ increased according to a power function with runoff (Fig. 4). There were substantial differences in mean daily runoff normalized by watershed area between the different stream types during the 25 June 2006 storm when denitrification was measured (Fig. 5). The forested sites, Pond Branch and Baisman Run, displayed peak flows that were an order of magnitude lower than the flashy peak flows at the unrestored urban sites, Dead Run and Scotts Level Branch. Minebank Run (restored) had a flashy peak $\left(230 \mathrm{~L} \cdot \mathrm{sec}^{-1} \cdot \mathrm{km}^{-2}\right)$ that was intermediate between forested and unrestored urban streams.

\section{Organic carbon source characterization}

Overall, there was a significant difference in molar $\mathrm{C}: \mathrm{N}$ ratios among site types $\left(F_{2,240}=23.14, N=245, P\right.$ $<0.01)$ and organic carbon sources $\left(F_{4,240}=21.89, P<\right.$ $0.01)$, and there was a significant interaction between site type and organic carbon source $\left(F_{8,240}=3.25, P<0.01\right.$; Fig. 6). The forested sites had a significantly higher mean C: $\mathrm{N}$ ratio, $22.9 \pm 1.1$, than the restored sites, 16.4 $\pm 0.8(t=5.99, P<0.01)$, and the unrestored urban sites, $16.6 \pm 0.9(t=5.44, P<0.01)$. Mean molar C:N ratios associated with leaves, $26.5 \pm 1.7$, were significantly higher than for periphyton, $19.3 \pm 1.5(t=4.67, P$ $<0.01)$, or grass, $18.3 \pm 0.8(t=4.90, P<0.01)$, and stream POM, $11.9 \pm 0.4(t=9.32, P<0.01)$. Mean molar $\mathrm{C}: \mathrm{N}$ ratios associated with stream POM were significantly lower than for grass $(t=4.41, P<0.01)$, periphyton $(t=4.64, P<0.01)$, and sediment $(t=5.26, P$ $<0.01)$.
Isotopic $\mathrm{C}$ and $\mathrm{N}$ signatures of grass clippings, leaf litter, and periphyton typically showed distinct separation with no overlap among sources in all five streams; But POM and sediment overlapped at Baisman Run (forested) and POM and leaves overlapped at Minebank Run (restored; Fig. 7). Across sites, mean $\delta^{13} \mathrm{C}$ signatures for grass clippings ranged from $-32.01 \%$ at Baisman Run (forested) to $-28.76 \%$ at Dead Run (unrestored urban); mean $\delta^{15} \mathrm{~N}$ for grass clippings ranged from $-1.69 \%$ at Pond Branch (forested) to $4.96 \%$ at Minebank Run (restored). Mean $\delta^{13} \mathrm{C}$ of leaf litter ranged from $-29.47 \%$ at Pond Branch (forested) to $-25.10 \%$ at Spring Branch (restored); mean $\delta^{15} \mathrm{~N}$ of leaf litter ranged from $-0.86 \%$ at Pond Branch (forested) to $2.69 \%$ at Spring Branch (restored). Mean $\delta^{13} \mathrm{C}$ of periphyton ranged from $-29.75 \%$ at Pond Branch (forested) to $-23.68 \%$ at Minebank Run (restored); mean $\delta^{15} \mathrm{~N}$ of periphyton ranged from $-2.63 \%$ at Pond Branch (forested) to $7.87 \%$ at Dead Run (unrestored urban). The isotopic signatures for POM and sediment were intermediate between the grass, leaf, and periphyton sources indicating a mixture of sources. Isotope biplots showed that at the forested sites, Pond Branch and Baisman Run, the POM and sediment were closest to the $\delta^{15} \mathrm{~N}$ and $\delta^{13} \mathrm{C}$ values of the leaf litter. This suggested that decayed leaves were an important source for POM and sediment among all site types, but especially at the forested sites (Fig. 7). At Minebank Run (restored), the isotopic signature for POM was similar to the leaf source. Isotopic signatures at Spring Branch (restored) and Dead Run (unrestored urban) also suggested that POM appeared to be a mixture of grass, periphyton, and decayed-leaf isotope signatures. At most sites, the POM signature was similar to the sediment signature except at Minebank Run (restored). 

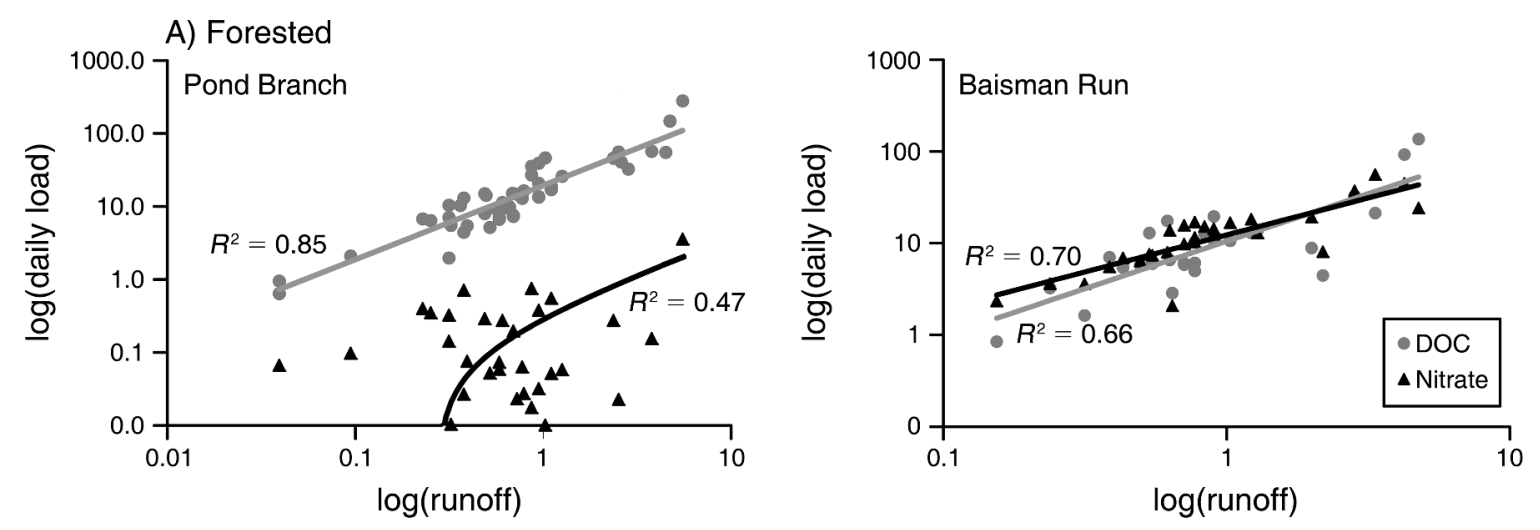

B) Restored
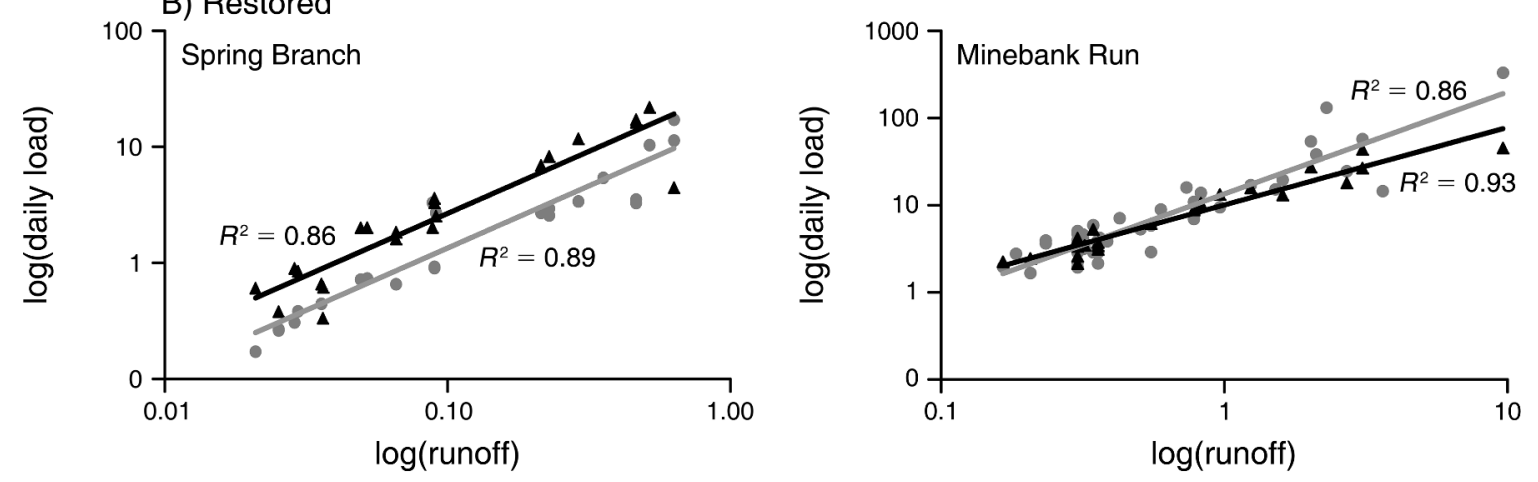

C) Unrestored urban
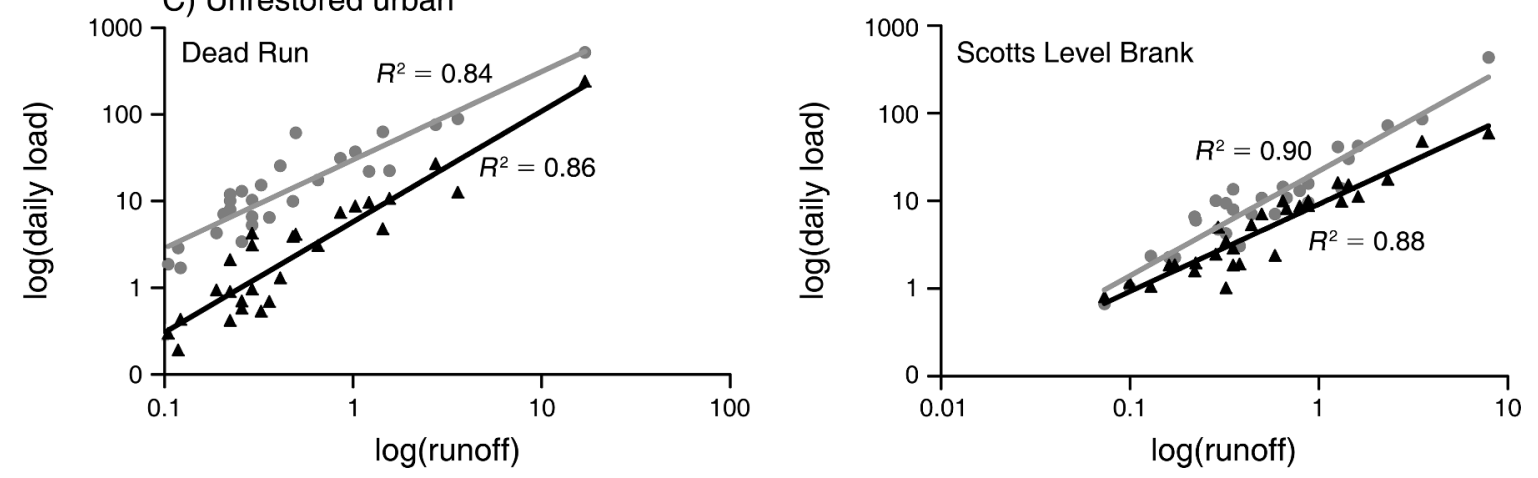

FIG. 4. Daily loads of DOC and nitrate (log-transformed; originally measured in $\mathrm{g} \cdot \mathrm{ha}^{-1} \cdot \mathrm{d}^{-1}$ ) vs. daily runoff (log-transformed; originally measured in $\mathrm{mm} / \mathrm{d}$ ) from (A) forested, (B) restored, and (C) unrestored urban watersheds. Daily loads of DOC and nitrate increased with daily runoff according to a power-law function at all sites, except for nitrate at the forested Pond Branch, which increased linearly.

Lipid biomarker results showed that the source and quality of organic matter varied across sites (Table 2). Long-chain alcohols and plant sterols serve as proxies for vascular plant (terrigenous) sources (Canuel and Martens 1993, Waterson and Canuel 2008). The percentages of long-chain alcohols were higher at Pond Branch (forested) than at Minebank Run (restored; $t=$ 2.23, $P=0.03$ ), while the percentage of plant sterols was higher at Spring Branch (restored) than at Pond Branch (forested; $t=2.68, P>0.01$ ) and Minebank Run (restored; $t=3.89, P=0.02$ ). The percentages of diatom sterols were lower at Pond Branch (forested) than at Minebank Run (restored; $t=2.09, P=0.04$ ).

Denitrification experiment 1: glucose vs. nitrate amendment

Denitrification potential was significantly higher when sediments were amended with glucose $(35.1 \pm 9.4 \mathrm{ng}$ $\mathrm{N} \cdot[\mathrm{g} \text { dry sediment }]^{-1} \cdot \mathrm{h}^{-1}$ ) than when amended with nitrate $\left(10.4 \pm 4.0 \mathrm{ng} \mathrm{N} \cdot[\mathrm{g} \text { dry sediment }]^{-1} \cdot \mathrm{h}^{-1} ; F_{1,46}=\right.$ $94.33, N=48, P=0.02$; Fig. 8). Denitrification potential was too low to detect in the nitrate amendment 


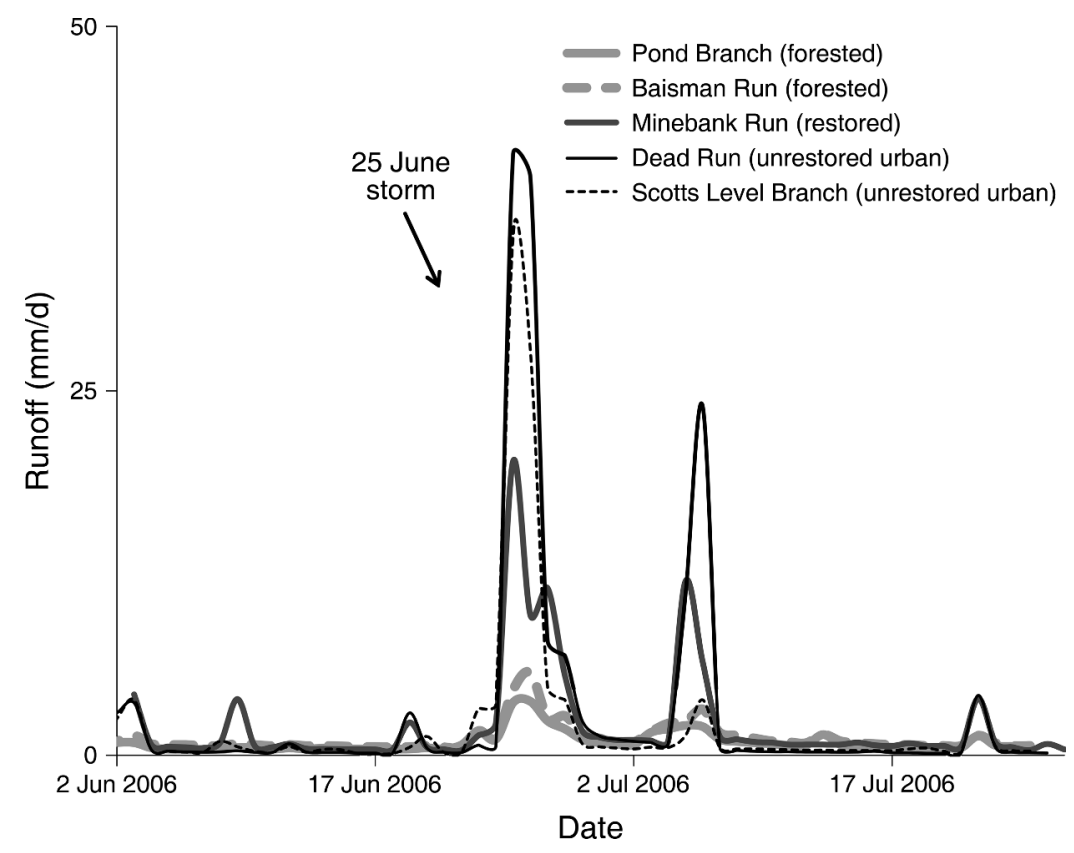

FIG. 5. Hydrograph of mean daily runoff of the storm that was sampled as part of the denitrification experiments (mm/d). Unrestored urban and restored sites have higher peak flows than forested sites. Data are lacking for Spring Branch because it does not have a real-time USGS flow monitoring station.

experiment at the forested site. Denitrification potential rates at forested streams $(2.2 \pm 1.0 \mathrm{ng} \mathrm{N} \cdot[\mathrm{g}$ dry sediment $\left.]^{-1} \cdot \mathrm{h}^{-1}\right)$ were significantly lower than at restored streams $\left(36.0 \pm 12.3 \mathrm{ng} \mathrm{N} \cdot[\mathrm{g} \text { dry sediment }]^{-1} \cdot \mathrm{h}^{-1}\right)$ and urban streams $(30.1 \pm 8.8 \mathrm{ng} \mathrm{N} \cdot[\mathrm{g}$ dry sediment $]^{-1} \cdot \mathrm{h}^{-1}$ ), but the rates measured at the restored and the unrestored urban sites were not significantly different $\left(F_{2,45}=4.29, N=48, P=0.02\right.$; Fig. 8). Denitrification potential rates associated with incubating sediments with stormflow streamwater $(29.6 \pm 9.4$ ng $\mathrm{N} \cdot[\mathrm{g} \text { dry sediment }]^{-1} \cdot \mathrm{h}^{-1}$ ) were consistently higher than with baseflow streamwater $(15.9 \pm 5.1 \mathrm{ng} \mathrm{N} \cdot[\mathrm{g}$ dry sediment $\left.]^{-1} \cdot \mathrm{h}^{-1}\right)$, but the difference was not statistically significant $\left(F_{2,45}=1.67, N=48, P=0.20\right.$; Fig. 8$)$.

\section{Denitrification experiment 2: effects of naturally occurring carbon sources on denitrification}

Denitrification potential rates from the experiment comparing the effects of naturally occurring organic carbon sources (control, periphyton, leaves, and grass), differed across site type $\left(F_{2,81}=3.79, N=86, P=0.01\right.$; Fig. 9B) and organic carbon source $\left(F_{3,60}=8.78, N=86\right.$, $P<0.01$; Fig. 9A). There was also a significant interaction between site type and organic carbon source $\left(F_{6,70}=2.33, N=86, P=0.02\right.$; Fig. 9$)$.

Denitrification potential rates (ng N.[g dry sediment $]^{-1} \cdot \mathrm{h}^{-1}$ ) were greatest when grass clippings were added as the naturally occurring organic carbon source $(1200 \pm 300)$ compared to periphyton $(410 \pm 110 ; t=$ 2.9, $P<0.01)$, leaves $(170 \pm 30 ; t=4.21, P<0.01)$, and control treatments $(3.1 \pm 1.7 ; t=4.63, P<0.01$; Fig. $9 \mathrm{~A})$. The highest denitrification potential rates were observed when sediments from Scotts Level Branch (unrestored urban) were incubated with the grass extract (7200 ng $\mathrm{N} \cdot[\mathrm{g} \text { dry sediment }]^{-1} \cdot \mathrm{h}^{-1}$ ). In addition, mean denitrification potential rates at the urban sites $(1000 \pm$ $\left.470 \mathrm{ng} \mathrm{N} \cdot[\mathrm{g} \text { dry sediment }]^{-1} \cdot \mathrm{h}^{-1}\right)$ were significantly higher than denitrification potential rates from the forested sites $\left(92 \pm 36 \mathrm{ng} \mathrm{N} \cdot[\mathrm{g} \text { dry sediment }]^{-1} \cdot \mathrm{h}^{-1} ; t=\right.$ $3.20, P<0.01)$ and the restored sites $(290 \pm 90 \mathrm{ng} \mathrm{N} \cdot[\mathrm{g}$ dry sediment $]^{-1} \cdot \mathrm{h}^{-1} ; t=2.51, P=0.01$; Fig. 9B). Mean denitrification potential rates across naturally occurring organic carbon sources were not significantly different between the forested and restored sites.

\section{Discussion}

\section{Variations in organic carbon amounts and sources across land use}

Our results demonstrate that urbanization causes shifts in organic carbon quantity, sources, and quality. We observed higher organic carbon concentrations and daily fluxes in urbanized streams than in forest streams. Urban streams can receive inputs from natural and/or anthropogenically enhanced organic carbon sources including leaf litter, autochthonous production, materials deposited on impervious surfaces, human and animal waste, and grass clippings from home lawns (Lofton et al. 2007, Sickman et al. 2007, Kaushal et al. 2011). Furthermore, urbanization can decrease canopy cover (Paul and Meyer 2001), and canopy coverage of riparian flow paths can influence the quantity and character of DOC delivered to streams and alter DOC bioavailability (Findlay et al. 2001, Pernet-Coudrier et al. 2010). 
Molar C:N ratios served as a second organic carbon source tracking method; higher values indicate potential terrestrial sources (Kaushal and Binford 1999). Both stable-isotope signatures and molar $\mathrm{C}: \mathrm{N}$ ratios suggested that POC sources and quality varied with watershed land use. Mean molar C:N ratios of organic carbon samples at the forested site were significantly higher than at the restored and the unrestored urban sites, indicating that organic matter at the forested sites may be lower in quality and more recalcitrant. The molar C:N ratios suggest that the forested site receives terrestrial organic matter such as leaves, while the restored and the unrestored urban sites receive a mixture of higher quality organic matter sources such as grass clippings, periphyton, and wastewater. Ratios of $\mathrm{C}: \mathrm{N}$ in streams influence $\mathrm{N}$ cycling (Dodds et al. 2004), and increasing the quantity of available DOC can enhance wholestream $\mathrm{N}$ uptake (Johnson et al. 2009) when $\mathrm{N}$ is not limiting heterotrophic production (e.g., Bernhardt and Likens 2002). Furthermore, these differential C: $\mathrm{N}$ ratios may affect denitrification and respiration rates in streams. Isotopic signatures suggested that terrestrial leaf sources contributed to POM in forested streams. In contrast, the POM in restored and unrestored urban streams was a mixture of periphyton, leaves, and grass. The $\delta^{15} \mathrm{~N}$ of the sediment in Minebank Run was considerably higher than other sites, and these high values may indicate denitrification or contamination from previous $\delta^{15} \mathrm{~N}$ tracer studies (Kaushal et al. 2008b). We used stable-isotope signatures of POM and sediment to indicate organic matter sources.

Lipid biomarker data provided another line of evidence that the source and amount of organic matter varied across land use and restoration status. Forested Pond Branch and Spring Branch (the older restoration) showed higher contributions from terrestrial sources than Minebank Run (the newer restoration). We speculate that Minebank Run showed lower contributions from terrestrial sources because trees planted in the restored riparian zone have not yet matured to full canopy coverage. The Minebank Run study reach that was restored between 2004 and 2005 had a significantly higher relative abundance of diatom carbon, indicating higher aquatic source contributions. Though lipid biomarker data were only available for a limited number of sites, these data provide further evidence that urbanization influences the source and quality of organic carbon in streams and the proportion of terrestrial vs. aquatic contributions.

Residential landscaping decisions like replacing forested areas with mowed lawns can also lead to considerable variability in riparian vegetation (Larson et al. 2009). For example, some riparian zones at our study sites consisted of managed lawns near streams with little or no tree canopy. Previous work analyzing stable isotopes from streams draining non-forested sites at the BES LTER site suggested an organic carbon contribution from lawns (Kaushal et al. 2011). There is

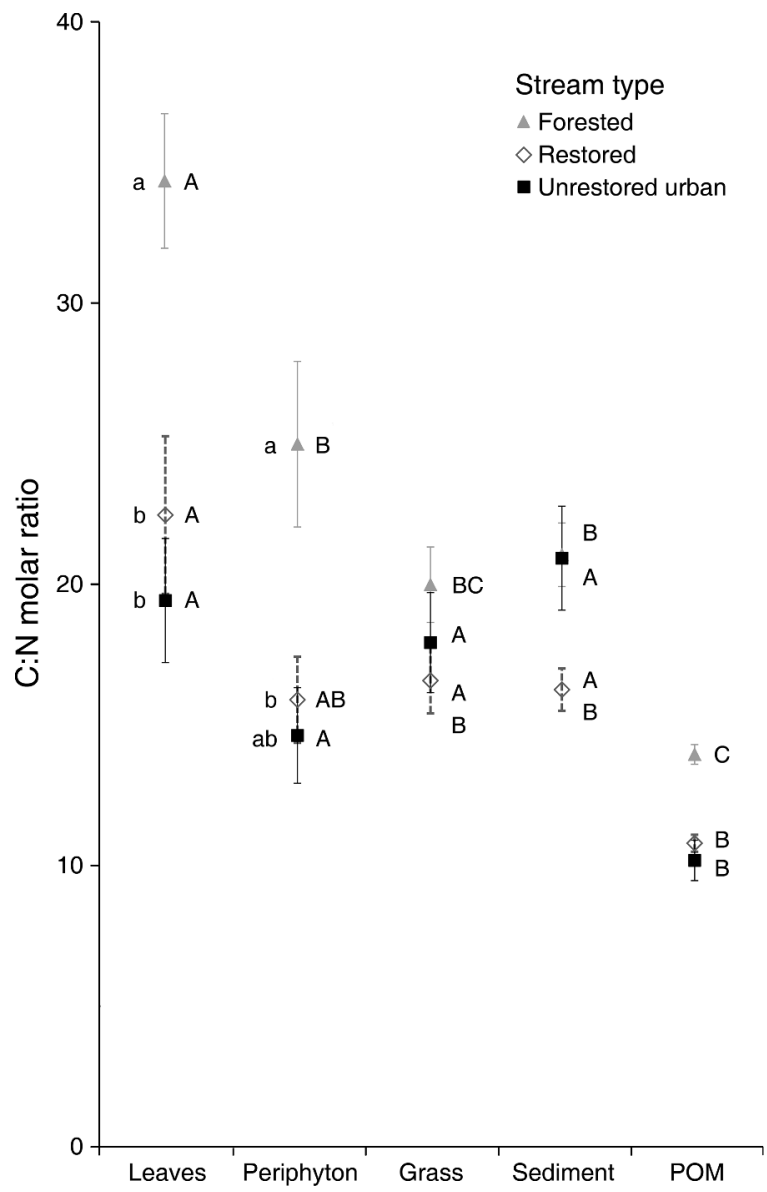

FIG. 6. Comparison of $\mathrm{C}: \mathrm{N}$ molar ratios for leaves, periphyton, grass, sediment, and particulate organic matter (POM) across forested $(N=20)$, restored $(N=14)$, and unrestored urban sites $(N=13)$. Values are means \pm SE. Letters represent comparisons (lowercase is inter-site type, and uppercase is intra-site type) that are significant $(\alpha=0.05)$ according to Tukey's studentized range (HSD) test.

evidence of organic carbon inputs to streams shifting from $\mathrm{C}_{3}$ plants (trees) to $\mathrm{C}_{4}$ plants (grasses) and changes in carbon quality with increasing urbanization (Kaushal et al. 2011). Our results from stable isotopes and C:N ratios are consistent with grass clippings contributing as a carbon source in urban streams. The total estimated area of urban lawns for the contiguous United States is $163800 \pm 35850 \mathrm{~km}^{2}$, which is three times greater than the area covered by irrigated corn (Milesi et al. 2005). Home lawns may have unique organic carbon dynamics when compared to native ecosystems (Kaye et al. 2005, Golubiewski 2006, Yesilonis et al. 2008, Groffman and Pouyat 2009). For example, lawn clippings are more labile than leaves from trees. Organic carbon from lawns may quickly turnover and enter food webs or may be rapidly decomposed by microbes and bypass higher trophic levels in food webs completely. Grassy riparian areas may alter biogeochemical cycling, food webs, and ecosystem functions like decomposition in ways that 

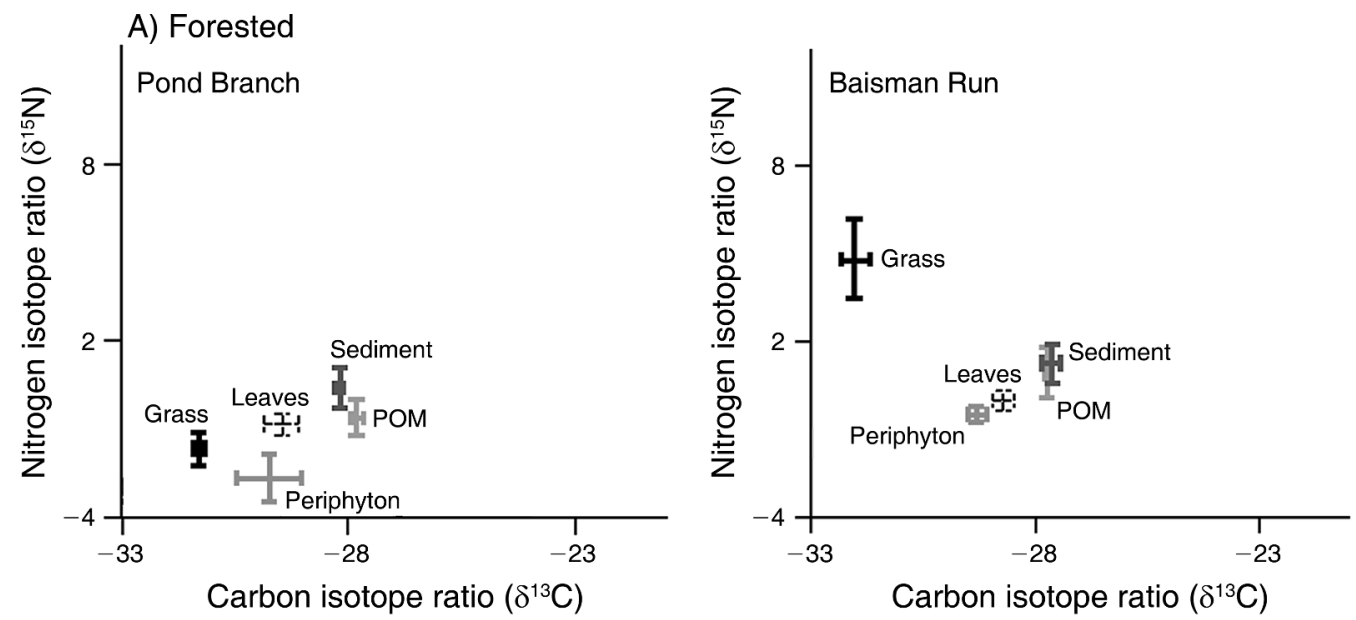

B) Restored
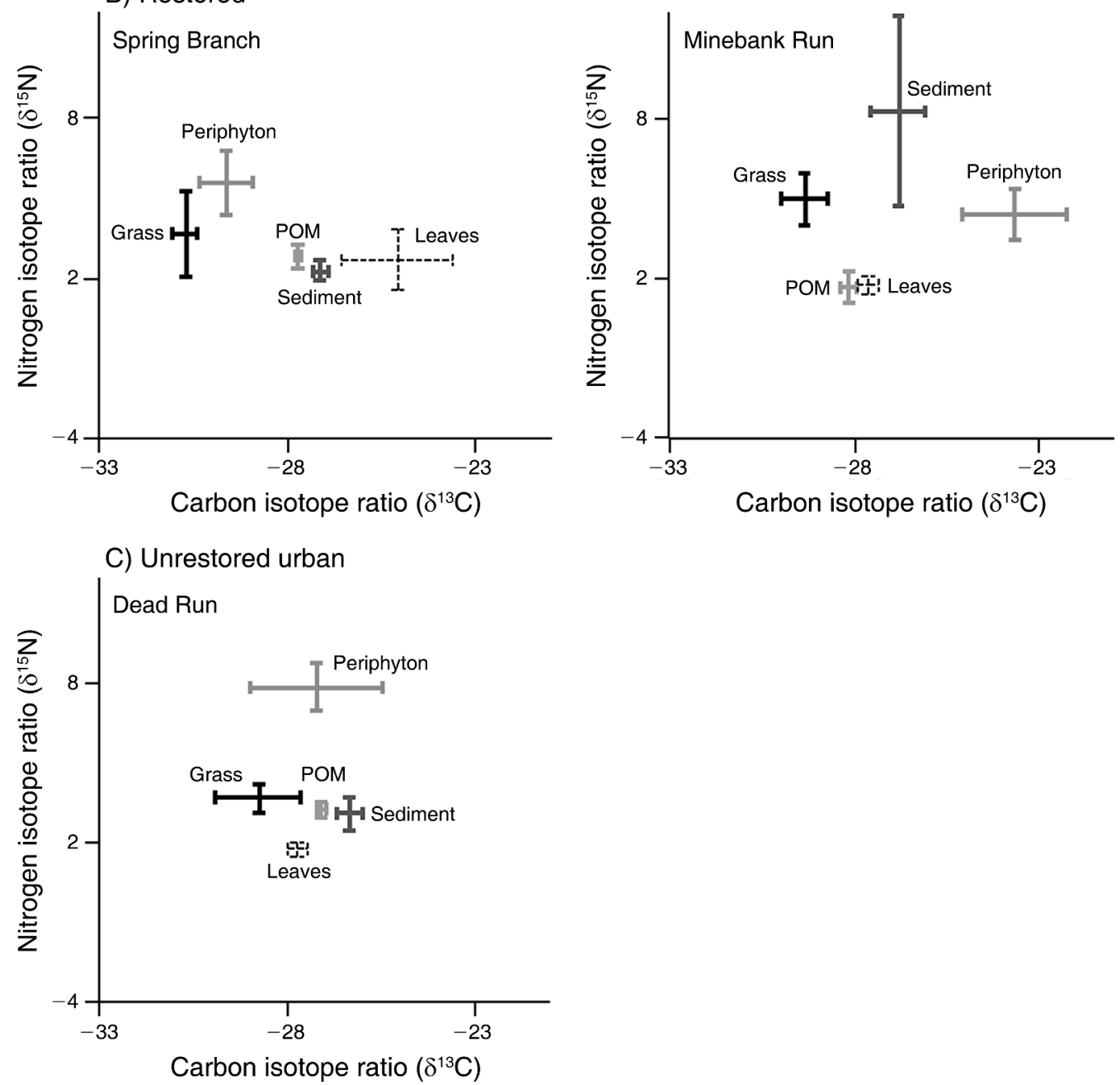

FIG. 7. Comparison of $\delta^{13} \mathrm{C}$ and $\delta^{15} \mathrm{~N}$ isotopic ratios in periphyton, leaves, grass, and particulate organic matter (POM) from (A) forested $(N=20),(\mathrm{B})$ restored $(N=14)$, and $(\mathrm{C})$ unrestored urban sites $(N=13)$. Values are means \pm SE. Scotts Level Branch was omitted because of cost and time constraints. 


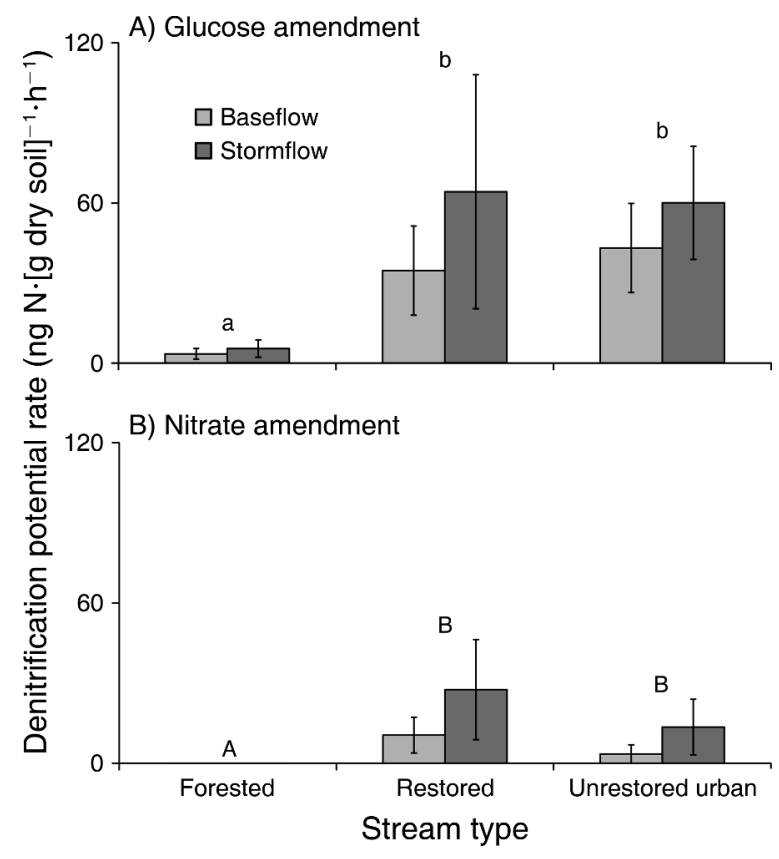

FIG. 8. Carbon amendments produced higher denitrification potential rates than nitrogen amendments to sediments incubated with streamwater collected during baseflow and stormflow conditions. Comparison of denitrification potential rates associated with sediments amended with (A) glucose and (B) nitrate. Values are means $\pm \mathrm{SE} ; N=4$ denitrification rate measurements for each bar. Letters above the bars represent comparisons between site types that are significant $(\alpha=0.05)$ according to Tukey's studentized range (HSD) test.

diverge from the river continuum model, which highlights the importance of leaf litter from trees (Vannote et al. 1980, Wiley et al. 1990, Kaushal and Belt 2012).

\section{Relative importance of organic carbon sources to denitrification in urban streams}

Urbanized streams are more likely to have flashy hydrology (Striz and Mayer 2008), and storms that carry nutrient- and DOC-rich water to the stream (Paul and Meyer 2001, Allan 2004). We did not observe a significant difference in denitrification rates between stormflow vs. baseflow. Our laboratory experiments showed that labile organic carbon availability can be more important in limiting denitrification than nitrate availability in our urban streams during baseflow and stormflow conditions. Previous studies suggest that nitrate concentrations are an important regulator of differences in denitrification potential; however, once levels of nitrate are sufficient (which occurs at fairly low suburban densities) organic carbon availability becomes important (Arango et al. 2007, Inwood et al. 2007).

Our results also suggest that shifts in natural organic matter may influence denitrification in urbanized and restored streams (Dosskey et al. 2010). The question of how different organic carbon sources can differentially influence denitrification rates extends broadly to fields as varied as prairie ecosystems, agriculture, and wastewater treatment (see Appendix A). We found that grass clippings from urban areas stimulated the highest denitrification rates. Periphyton produced intermediate rates across sites. Clipping and blending the grass may have led to larger changes in DOM availability than harvesting and blending of leaves or periphyton. While it might have been preferable to compare fresh leaves with the clippings, we note that clippings are produced and transported to the stream throughout the growing season, while leaves are only produced once per year during autumn. Therefore, comparing fresh clippings and leaves and periphyton resident in the stream channel may actually be more realistic of in situ conditions. Although decaying leaves collected from the stream had diminished DOM availability because rapid loss of

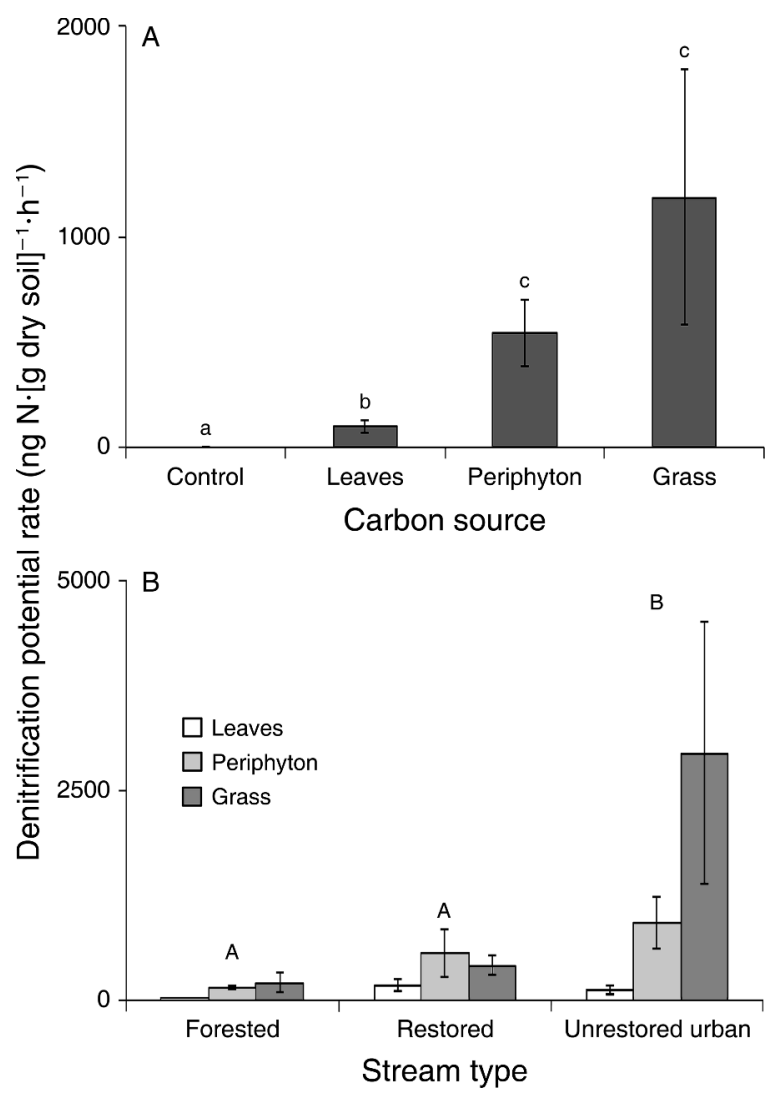

FIG. 9. Comparison of denitrification potential rates associated with different naturally occurring organic carbon sources at two forested (Pond Branch and Baisman Run), two restored (Spring Branch and Minebank), and two unrestored urban (Dead Run and Scotts Level Branch) streams. Values are means \pm SE. Letters above the bars represent comparisons (lowercase is carbon source, and uppercase is stream type) that are significant $(\alpha=0.05)$ according to Tukey's studentized range (HSD) test. (A) Results from all six sites are averaged and divided into categories of organic carbon sources, and (B) data are divided by site type and organic carbon source. Some data bars appear to be missing because the potential rates were comparatively low in (A) control and (B) leaves at the forested site. 
TABLE 2. Lipid biomarker data from two locations at forested Pond Branch, two locations at restored Spring Branch, and three locations at restored Minebank Run streams (Canuel and Martens 1993, Waterson and Canuel 2008).

\begin{tabular}{|c|c|c|c|c|c|c|}
\hline \multirow[b]{4}{*}{ Site } & \multicolumn{6}{|c|}{ Lipid biomarkers } \\
\hline & \multirow[b]{3}{*}{$\begin{array}{l}\text { Terrestrial : aquatic } \\
\text { fatty acid ratio }\end{array}$} & \multicolumn{5}{|c|}{ Terrestrial-source indicators } \\
\hline & & \multirow[b]{2}{*}{$\begin{array}{c}\text { Long-chain } \\
\text { fatty acids (\%) }\end{array}$} & \multicolumn{2}{|c|}{ Long-chain alcohols } & \multicolumn{2}{|c|}{ Plant sterols } \\
\hline & & & Percentage & $\begin{array}{c}\text { Tukey } \\
\text { comparison }\end{array}$ & Percentage & $\begin{array}{c}\text { Tukey } \\
\text { comparison }\end{array}$ \\
\hline Pond Branch & & & & $\mathrm{A}$ & & $\mathrm{A}$ \\
\hline Forested site 1 & $0.17 \pm 0.11$ & $3.99 \pm 2.34$ & $29.40 \pm 11.88$ & & $47.68 \pm 11.29$ & \\
\hline Forested site 2 & $0.36 \pm 0.07$ & $7.10 \pm 0.29$ & $37.56 \pm 8.45$ & & $56.44 \pm 16.23$ & \\
\hline Spring Branch & & & & $\mathrm{AB}$ & & $\mathrm{B}$ \\
\hline Restored $1994-1997$ site 1 & $0.56 \pm 0.27$ & $11.67 \pm 3.90$ & $45.68 \pm 2.62$ & & $76.49 \pm 0.85$ & \\
\hline Restored 1994-1997 site 2 & $0.05 \pm 0.01$ & $1.36 \pm 0.37$ & $16.06 \pm 2.24$ & & $68.36 \pm 1.63$ & \\
\hline Minebank Run & & & & B & & A \\
\hline Restored 1998-1999 site 1 & $0.04 \pm 0.02$ & $0.83 \pm 0.46$ & $28.98 \pm 4.31$ & & $38.93 \pm 8.22$ & \\
\hline Restored $1998-1999$ site 2 & $0.05 \pm 0.05$ & $1.16 \pm 1.16$ & $19.00 \pm 3.23$ & & $66.02 \pm 3.07$ & \\
\hline Restored $2004-2005$ site 3 & $0.01 \pm 0.01$ & $0.29 \pm 0.29$ & $5.978 \pm 0.54$ & & $31.27 \pm 0.16$ & \\
\hline
\end{tabular}

soluble leaf constituents occurs after immersion, decaying leaves are still an important source of DOM because, as they sit in streams, they are colonized by fungi and other microorganisms that continue to break down the leaf matrix and release DOC while building an organic carbon-rich biofilm (Gessner et al. 1999). Thus, our results show that fresh lawn clippings may have substantial short-term effects on $\mathrm{N}$ removal via denitrification, while leaves and periphyton may have more sustained $\mathrm{N}$ removal over time at a lower instantaneous denitrification rate. Overall, higher denitrification rates occurred in the urban sites, intermediate denitrification in the restored sites, and relatively lower denitrification in the forested sites. Possible reasons for higher denitrification potential rates in urban areas are elevated nitrate concentrations and organic carbon quality (Groffman et al. 2005, Harrison et al. 2011).

In order to understand how changes in organic carbon sources might influence the mass balance of nitrate in a stream, we multiplied measured DOC loads by published bioavailability values to estimate the amount of denitrification that could be potentially supported at each site.

Reported ranges for DOC bioavailability in forested streams included $0-40 \%$ in the Rocky Mountains of
Colorado, USA (Kaushal and Lewis 2005), and $21 \pm$ $7 \%$ in New Jersey, USA (Wiegner and Seitzinger 2004), and $\sim 2 \%$ in Swan-Canning catchments in Australia (Petrone et al. 2009).

In urban streams, DOC bioavailability ranged from $16 \%$ to $17 \%$ with a mode of $16 \%$ (Petrone et al. 2009). We used a value of $16 \%$ DOC bioavailability for the urban streams, as well as for the restored streams because we could not find literature values of DOC bioavailability in restored streams. Bioavailability of organic carbon varies across geography and studies, so we opted to use values from a common study that examined both urban and forested land uses (Petrone et al. 2009). We estimated the percentage of daily nitrate load reduction $(\mathrm{kg} / \mathrm{d})$ that may be possible with bioavailable DOC from each stream using the following formula:

$$
\mathrm{NO}_{3}^{-} \text {load reduction }=100 \times \frac{\text { bioavailability } \times \text { DOC load }}{\mathrm{NO}_{3}^{-} \text {load } \times 4}
$$

where bioavailability is the percentage of DOC that is assumed to be bioavailable, DOC load is the mean daily DOC load $(\mathrm{kg} / \mathrm{d})$, and $\mathrm{NO}_{3}{ }^{-}$load is the mean daily nitrate load $(\mathrm{kg} / \mathrm{d})$. The equation is divided by 4 because $4 \mathrm{mg}$ of $\mathrm{CBOD}$ are needed for each $\mathrm{mg}$ of nitrate

TABLE 3. Estimation of potential nitrate load reduction through denitrification based upon available DOC and literature ranges for DOC bioavailability (from Petrone et al. 2009).

\begin{tabular}{lrrrrrrr}
\hline \hline \multicolumn{1}{c}{ Stream } & \multicolumn{1}{c}{$\begin{array}{c}\text { Mean } \\
(\mathrm{L} / \mathrm{d})\end{array}$} & $\begin{array}{c}\text { Estimated } \\
\text { bioavailability } \\
(\%)\end{array}$ & $\begin{array}{c}\text { DOC } \\
(\mathrm{kg} / \mathrm{d})\end{array}$ & $\begin{array}{c}\text { Bioavailable } \\
\text { DOC (kg/d) }\end{array}$ & $\begin{array}{c}\text { Bioavailable } \\
\text { DOC } \\
(\mathrm{kg} / \mathrm{d}) \div 4\end{array}$ & $\begin{array}{c}\text { Mean } \\
\text { nitrate } \\
(\mathrm{kg} / \mathrm{d})\end{array}$ & $\begin{array}{c}\text { Potential } \\
\text { nitrate load } \\
\text { removal }(\%)\end{array}$ \\
\hline Pond Branch (forested) & 345279 & 108 & 2 & 2.16 & 0.54 & 1 & 54 \\
Baisman Run (forested) & 4653736 & 874 & 2 & 17.48 & 4.37 & 747 & 1 \\
Spring Branch (restored) & 23608 & 5 & 16 & 0.80 & 0.22 & 9 & 2 \\
Minebank Run (restored) & 5261577 & 1319 & 16 & 211.04 & 52.76 & 859 & 6 \\
Dead Run (unrestored urban) & 18192911 & 7430 & 16 & 1188.80 & 297.19 & 2497 & 12 \\
Scotts Level Branch (unrestored urban) & 8103227 & 3415 & 16 & 546.40 & 136.60 & 1029 & 13 \\
\hline
\end{tabular}


TABLE 2. Extended.

\begin{tabular}{lcc}
\hline \hline \multicolumn{3}{c}{ Lipid biomarkers } \\
\hline & Aquatic-source indicators & \\
\cline { 2 - 3 } Short-chain & \multicolumn{2}{c}{ Diatom sterols } \\
alcohols (\%) & Percentage & $\begin{array}{c}\text { Tukey } \\
\text { comparison }\end{array}$ \\
\hline & & $\mathrm{A}$ \\
$32.62 \pm 13.27$ & $0.89 \pm 0.89$ & \\
$17.59 \pm 8.48$ & $6.30 \pm 1.76$ & $\mathrm{AB}$ \\
& & \\
$11.92 \pm 1.24$ & $1.92 \pm 0.18$ & $\mathrm{~B}$ \\
$9.84 \pm 0.97$ & $9.69 \pm 0.35$ & \\
& & \\
$17.31 \pm 3.60$ & $6.68 \pm 0.52$ & \\
$25.34 \pm 6.05$ & $7.30 \pm 0.25$ & \\
$9.51 \pm 0.59$ & $40.41 \pm 3.36$ & \\
\hline
\end{tabular}

removed (U.S. EPA 1993). Results show that Pond Branch (forested) has ample carbon for 54\% removal of nitrate by denitrification, while Baisman Run (forested) is more limited because it has high nitrate loading from septic systems and less bioavailable DOC. At the urban sites, bioavailable DOC load is highly limiting to denitrification despite higher bioavailability (Table 3). Even if the DOC load were $100 \%$ bioavailable, there would not be enough for complete denitrification at Spring Branch (restored); instead, it would only be enough for denitrification of $14 \%$ of the nitrate load. Thus, according to this estimate, bioavailable DOC limits $\mathrm{N}$ removal through denitrification at all sites besides Pond Branch (forested), where nitrate concentrations are relatively low.

\section{Implications for riparian management and restoration}

Studies of stream restoration effects on ecosystem functions such as $\mathrm{N}$ cycling are limited but growing (Bukaveckas 2007, Roberts et al. 2007, Kaushal et al. 2008b, Klocker et al. 2009, Sivirichi et al. 2011). Previous work has shown linkages between DOC and nitrate (Munn and Meyer 1990, Mayer et al. 2010, Sivirichi et al. 2011) and indicate that management efforts to increase groundwater residence time and increase DOC availability may improve $\mathrm{N}$ removal capacity (Striz and Mayer 2008, Mayer et al. 2010). Integrated stormwater management and stream restoration may be a means to foster $\mathrm{N}$ removal capacity by enhancing denitrification in some cases by increasing availability of organic carbon, stream-floodplain interaction, and increasing residence time (Collins et al. 2010, Mayer et al. 2010, Sivirichi et al. 2011). Denitrification rate potentials in restored streams have been shown to increase with increasing amounts of organic carbon in riparian-zone sediments (Gift et al. 2010) and debris dams (Groffman et al. 2005, Harrison et al. 2012). Surprisingly, organic carbon from residential lawns was shown to impact the $\mathrm{N}$ cycle of streams more than background sources. Given that C:N stoichiometry can be an important influence on denitrification, management strategies that increase organic carbon relative to $\mathrm{N}$ may increase $\mathrm{N}$ removal (Park et al. 2008, Taylor and Townsend 2010). Therefore, an improved understanding of coupled carbon and nitrogen biogeochemical cycles in urban watersheds is critical for enhancing denitrification and $\mathrm{N}$ removal along larger managed stream networks (Sivirichi et al. 2011, Kaushal and Belt 2012).

\section{Conclusions}

We found that concentrations and loads of nitrate and DOC varied with runoff and there were elevated loads of organic carbon at urban sites. Stable-isotope and lipid biomarker data demonstrate that urbanization alters the amount and source of organic carbon delivered to streams. Management of riparian vegetation influences denitrification rates at the riparian-stream interface. Managing amounts, sources, and quality of organic carbon is critical for managing nitrogen flux in stormwater management systems and urban restoration stream projects. Future work should investigate how specific restoration and stormwater management strategies impact the coupling of carbon and nitrogen cycles, and assess the implications for managing denitrification in human-dominated watersheds.

\section{ACKNOWLEDGMenTS}

This research was supported by Maryland Sea Grant Awards SA7528085-U, R/WS-2 and NA05OAR4171042, NSF Awards DBI 0640300 and CBET 1058502, EPA NNEMS Award 2010308, NASA grant NASA NNX11AM28G, the U.S. EPA Office of Research and Development, and Baltimore Ecosystem Study LTER project (NSF DEB-0423476). E. Canuel was supported by NSF Awards DEB-0542645 and OCE 0962277 during the study period. We thank Melissa Grese, Katie Newcomb, Gwen Sivirichi, Stuart Findlay, David Lewis, and Elizabeth Lerberg for assistance in the laboratory and field. The research has not been subjected to U.S. Environmental Protection Agency review and therefore does not necessarily reflect the views of any of the funding agencies, and no official endorsement should be inferred. This paper is Contribution 3236 of the Virginia Institute of Marine Science, the College of William and Mary.

\section{Literature Cited}

Allan, J. D. 2004. Landscapes and riverscapes: the influence of land use on stream ecosystems. Annual Review of Ecology, Evolution, and Systematics 35:257-284.

Arango, C. P., J. L. Tank, J. L. Schaller, T. V. Royer, M. J. Bernot, and M. B. David. 2007. Benthic organic carbon influences denitrification in streams with high nitrate concentration. Freshwater Biology 52:1210-1222.

Bernhardt, E. S., R. O. Hall, Jr., and G. E. Likens. 2002. Whole-system estimates of nitrification and nitrate uptake in streams of the Hubbard Brook Experimental Forest. Ecosystems 5:419-430.

Bernhardt, E. S., and G. E. Likens. 2002. Dissolved organic carbon enrichment alters nitrogen dynamics in a forest stream. Ecology 83:1689-1700.

Boesch, D. F., R. B. Brinsfield, and R. E. Magnien. 2001. Chesapeake Bay eutrophication: scientific understanding, ecosystem restoration, and challenges for agriculture. Journal of Environment Quality 30:303-320. 
Boyer, E. W., R. B. Alexander, W. J. Parton, C. Li, K. Butterbach-Bahl, S. D. Donner, R. W. Skaggs, and S. J. D. Grosso. 2006. Modeling denitrification in terrestrial and aquatic ecosystems at regional scales. Ecological Applications 16:2123-2142.

Bukaveckas, P. A. 2007. Effects of channel restoration on water velocity, transient storage, and nutrient uptake in a channelized stream. Environmental Science and Technology 41:1570-1576.

Canuel, E. A., and C. S. Martens. 1993. Seasonal variations in the sources and alteration of organic matter associated with recently-deposited sediments. Organic Geochemistry 20:563577.

Carpenter, S. R., N. F. Caraco, D. L. Correll, R. W. Howarth, A. N. Sharpley, and V. H. Smith. 1998. Nonpoint pollution of surface waters with phosphorus and nitrogen. Ecological Applications 8:559-568.

Collins, K. A., T. J. Lawrence, E. K. Stander, R. J. Jontos, S. S. Kaushal, T. A. Newcomer, N. B. Grimm, and. M. L. Cole Ekberg. 2010. Opportunities and challenges for managing nitrogen in urban stormwater: A review and synthesis. Ecological Engineering 36:1507-1519.

Davidson, E. A., and J. P. Schimel. 1995. Microbial processes of production and consumption of nitric oxide, nitrous oxide and methane. Pages 327-357 in P. A. Matson, and R. C. Harriss, editors. Biogenic trace gases: measuring emissions from sediment and water. Blackwell Science, Cambridge, Massachusetts, USA.

DEPRM [Department of Environmental Protection and Resource Management]. 2008a. Spring Branch subwatershed-small watershed action plan; addendum to the water quality management plan for Loch Raven watershed. Volume 1. DEPRM, Towson, Maryland, USA. http://resources.baltimorecountymd. gov/Documents/Environment/Watersheds/swapspringbranchvol\% 201.pdf

DEPRM. 2008b. Spring Branch subwatershed - small watershed action plan; addendum to the water quality management plan for Loch Raven watershed. Volume 2: Appendices D-G. DEPRM, Towson, Maryland, USA. http://resources.baltimorecountymd. gov/Documents/Environment/Watersheds/swapspringbranchvol2. pdf

Dodds, W., E. Martí, J. Tank, J. Pontius, S. Hamilton, N. Grimm, W. Bowden, W. McDowell, B. Peterson, H. M Valett, J. Webster, and S. Gregory. 2004. Carbon and nitrogen stoichiometry and nitrogen cycling rates in streams. Oecologia 140

Doheny, E. J., J. J. A. Dillow, P. M. Mayer, and E. A. Striz. 2012. Geomorphic responses to stream channel restoration at Minebank Run, Baltimore County, Maryland, 2002-08. Scientific Investigations Report 2012-5012. USGS, Baltimore, Maryland, USA. http://pubs.usgs.gov/sir/2012/5012/

Doheny, E. J., R. J. Starsoneck, E. A. Striz, and P. M. Mayer. 2006. Watershed characteristics and pre-restoration surfacewater hydrology of Minebank Run, Baltimore County, Maryland, water years 2002-04. Scientific Investigations Report 2006-5179. USGS, Baltimore, Maryland, USA. http://pubs.usgs.gov/sir/2006/5179/

Dosskey, M. G., P. Vidon, N. P. Gurwick, C. J. Allan, T. P. Duval, and R. Lowrance. 2010. The role of riparian vegetation in protecting and improving chemical water quality in streams. Journal of the American Water Resources Association 46:261-277.

Edwards, R. T., and J. L. Meyer. 1987. Metabolism of a subtropical low gradient blackwater river. Freshwater Biology 17:251-263.

Findlay, S., J. M. Quinn, C. W. Hickey, G. Burrell, and M. Downes. 2001. Effects of land use and riparian flowpath on delivery of dissolved organic carbon to streams. Limnology and Oceanography 46:345-355.

Findlay, S., and R. L. Sinsabaugh. 1999. Unravelling the sources and bioavailability of dissolved organic matter in lotic aquatic ecosystems. Marine and Freshwater Research 50:781.

Fisher, S. G., and G. E. Likens. 1973. Energy flow in Bear Brook, New Hampshire: an integrative approach to stream ecosystem metabolism. Ecological Monographs 43:421-439.

Frost, P. C., J. H. Larson, L. E. Kinsman, G. A. Lamberti, and S. D. Bridgham. 2005. Attenuation of ultraviolet radiation in streams of northern Michigan. Journal of the North American Benthological Society 24:246-255.

Gessner, M. O., E. Chauvet, and M. Dobson. 1999. A perspective on leaf litter breakdown in streams. Oikos 85:377-384.

Gift, D. M., P. M. Groffman, S. S. Kaushal, and P. M. Mayer. 2010. Denitrification potential, root biomass, and organic matter in degraded and restored urban riparian zones. Restoration Ecology 18:113-120.

Golubiewski, N. E. 2006. Urbanization increases grassland carbon pools: effects of landscaping in Colorado's Front Range. Ecological Applications 16:555-571.

Griffiths, N. A., J. L. Tank, T. V. Royer, E. J. Rosi-Marshall, M. R. Whiles, C. P. Chambers, T. C. Frauendorf, and M. A. Evans-White. 2009. Rapid decomposition of maize detritus in agricultural headwater streams. Ecological Applications 19:133-142.

Groffman, P. M., M. A. Altabet, J. K. Böhlke, K. ButterbachBahl, M. B. David, M. K. Firestone, A. E. Giblin, T. M. Kana, L. P. Nielsen, and M. A. Voytek. 2006. Methods for measuring denitrification: diverse approaches to a difficult problem. Ecological Applications 16:2091-2122.

Groffman, P. M., A. M. Dorsey, and P. M. Mayer. 2005. N processing within geomorphic structures in urban streams. Journal of the North American Benthological Society 24:613-625.

Groffman, P. M., E. Holland, D. D. Myrold, G. P. Robertson, and X. Zou. 1999. Denitrification. Pages 272-288 in G. P. Robertson, C. S. Bledsoe, D. C. Coleman, and P. Sollins, editors. Standard soil methods for long-term ecological research. Oxford University Press, New York, New York, USA.

Groffman, P. M., N. L. Law, K. T. Belt, L. E. Band, and G. T. Fisher. 2004. Nitrogen fluxes and retention in urban watershed ecosystems. Ecosystems 7:393-403.

Groffman, P. M., and R. V. Pouyat. 2009. Methane uptake in urban forests and lawns. Environmental Science and Technology 43:5229-5235.

Harrison, M. D., P. M. Groffman, P. M. Mayer, and S. S. Kaushal. 2012. Microbial biomass and activity in geomorphic features in forested and urban restored and degraded streams. Ecological Engineering 38:1-10.

Harrison, M. D., P. M. Groffman, P. M. Mayer, S. S. Kaushal, and T. A. Newcomer. 2011. Denitrification in alluvial wetlands in an urban landscape. Journal of Environment Quality 40:634-646.

Hedin, L. O., J. C. von Fischer, N. E. Ostrom, B. P. Kennedy, M. G. Brown, and G. P. Robertson. 1998. Thermodynamic constraints on nitrogen transformations and other biogeochemical processes at soil-stream interfaces. Ecology 79:684703

Hook, A. M., and J. A. Yeakley. 2005. Stormflow dynamics of dissolved organic carbon and total dissolved nitrogen in a small urban watershed. Biogeochemistry 75:409-431.

Howarth, R. W., D. P. Swaney, E. W. Boyer, R. Marino, N. Jaworski, and C. Goodale. 2006. The influence of climate on average nitrogen export from large watersheds in the Northeastern United States. Biogeochemistry 79:163-186.

Inwood, S. E., J. L. Tank, and M. J. Bernot. 2007. Factors controlling sediment denitrification in midwestern streams of varying land use. Microbial Ecology 53:247-258.

Johnson, L. T., J. L. Tank, and C. P. Arango. 2009. The effect of land use on dissolved organic carbon and nitrogen uptake in streams. Freshwater Biology 54:2335-2350. 
Kaushal, S. S., and K. T. Belt. 2012. The urban watershed continuum: evolving spatial and temporal dimensions. Urban Ecosystems 15:409-435.

Kaushal, S. S., and M. W. Binford. 1999. Relationship between $\mathrm{C}: \mathrm{N}$ ratios of lake sediments, organic matter sources, and historical deforestation in Lake Pleasant, Massachusetts, USA. Journal of Paleolimnology 22:439-442.

Kaushal, S. S., P. M. Groffman, L. E. Band, E. M. Elliott, C. A. Shields, and C. Kendall. 2011. Tracking nonpoint source nitrogen pollution in human-impacted watersheds. Environmental Science and Technology 45:8225-8232.

Kaushal, S. S., P. M. Groffman, L. E. Band, C. A. Shields, R. P. Morgan, M. A. Palmer, K. T. Belt, C. M. Swan, S. E. G. Findlay, and G. T. Fisher. 2008a. Interaction between urbanization and climate variability amplifies watershed nitrate export in Maryland. Environmental Science and Technology 42:5872-5878.

Kaushal, S. S., P. M. Groffman, P. M. Mayer, E. Striz, and A. J. Gold. 2008b. Effects of stream restoration on denitrification in an urbanizing watershed. Ecological Applications 18:789-804.

Kaushal, S. S., and W. M. Lewis. 2003. Patterns in the chemical fractionation of organic nitrogen in Rocky Mountain streams. Ecosystems 6:483-492.

Kaushal, S. S., and W. M. Lewis. 2005. Fate and transport of organic nitrogen in minimally disturbed montane streams of Colorado, USA. Biogeochemistry 74:303-321.

Kaushal, S. S., M. L. Pace, P. M. Groffman, L. E. Band, P. M. Mayer, and C. Welty. 2010. Land use and climate variability amplify contaminant pulses. Eos, Transactions, American Geophysical Union 91:221-222.

Kaye, J. P., R. L. McCulley, and I. C. Burke. 2005. Carbon fluxes, nitrogen cycling, and soil microbial communities in adjacent urban, native and agricultural ecosystems. Global Change Biology 11:575-587.

Kemp, W. M., et al. 2005. Eutrophication of Chesapeake Bay: historical trends and ecological interactions. Marine Ecology Progress Series 303:1-29.

Klocker, C. A., S. S. Kaushal, P. M. Groffman, P. M. Mayer, and R. P. Morgan. 2009. Nitrogen uptake and denitrification in restored and unrestored streams in urban Maryland, USA. Aquatic Sciences 71:411-424.

Krasner, S. W., M. J. McGuire, J. G. Jacangelo, N. L. Patania, K. M. Reagan, and E. M. Aieta. 1989. The occurrence of disinfection by-products in United States drinking-water. Journal of the American Water Works Association 81:41-53.

Kraus, T., B. Bergamaschi, P. Hernes, R. Spencer, R. Stepanauskas, C. Kendall, R. Losee, and R. Fujii. 2008. Assessing the contribution of wetlands and subsided islands to dissolved organic matter and disinfection byproduct precursors in the Sacramento-San Joaquin River Delta: A geochemical approach. Organic Geochemistry 39:1302-1318.

Larson, K. L., D. Casagrande, S. L. Harlan, and S. T. Yabiku. 2009. Residents' yard choices and rationales in a desert city: social priorities, ecological impacts, and decision tradeoffs. Environmental Management 44:921-937.

Lofton, D. D., A. E. Hershey, and S. C. Whalen. 2007. Evaluation of denitrification in an urban stream receiving wastewater effluent. Biogeochemistry 86:77-90.

Mayer, P. M., P. M. Groffman, E. A. Striz, and S. S. Kaushal. 2010. Nitrogen dynamics at the groundwater-surface water interface of a degraded urban stream. Journal of Environmental Quality 39:810-823.

McCutchan, J. H., Jr., and W. M. Lewis, Jr. 2002. Relative importance of carbon sources for macroinvertebrates in a Rocky Mountain stream. Limnology and Oceanography 47:742-752.

McDowell, W. H., and G. E. Likens. 1988. Origin, composition, and flux of dissolved organic carbon in the Hubbard Brook Valley. Ecological Monographs 58:177-195.
Milesi, C., S. W. Running, C. D. Elvidge, J. B. Dietz, B. T. Tuttle, and R. R. Nemani. 2005. Mapping and modeling the biogeochemical cycling of turf grasses in the United States. Environmental Management 36:426-438.

Munn, N. L., and J. L. Meyer. 1990. Habitat-specific solute retention in two small streams: an intersite comparison. Ecology 71:2069-2082.

Park, J., R. Craggs, and J. Sukias. 2008. Treatment of hydroponic wastewater by denitrification filters using plant prunings as the organic carbon source. Bioresource Technology 99:2711-2716.

Paul, M. J., and J. L. Meyer. 2001. Streams in the urban landscape. Annual Review of Ecology and Systematics 32:333-365.

Paul, M. J., J. L. Meyer, and C. A. Couch. 2006. Leaf breakdown in streams differing in catchment land use. Freshwater Biology 51:1684-1695.

Perdue, E. M., K. C. Beck, and J. H. Reuter. 1976. Organic complexes of iron and aluminum in natural waters. Nature 260:418-420.

Pernet-Coudrier, B., G. Varrault, M. Saad, J. P. Croue, M.-F. Dignac, and J.-M. Mouchel. 2010. Characterisation of dissolved organic matter in Parisian urban aquatic systems: predominance of hydrophilic and proteinaceous structures. Biogeochemistry 106:89-106.

Petrone, K. C. 2010. Catchment export of carbon, nitrogen, and phosphorus across an agro-urban land use gradient, SwanCanning River system, southwestern Australia. Journal of Geophysical Research 115:G01016.

Petrone, K. C., J. B. Fellman, E. Hood, M. J. Donn, and P. F. Grierson. 2011. The origin and function of dissolved organic matter in agro-urban coastal streams. Journal of Geophysical Research 116:G01028.

Petrone, K. C., J. S. Richards, and P. F. Grierson. 2009. Bioavailability and composition of dissolved organic carbon and nitrogen in a near coastal catchment of south-western Australia. Biogeochemistry 92:27-40.

Pickett, S. T. A., M. L. Cadenasso, J. M. Grove, C. G. Boone, P. M. Groffman, E. Irwin, S. S. Kaushal, V. Marshall, B. P. McGrath, and C. H. Nilon. 2011. Urban ecological systems: Scientific foundations and a decade of progress. Journal of Environmental Management 92:331-362.

Pouyat, R. V., I. D. Yesilonis, and N. E. Golubiewski. 2009. A comparison of soil organic carbon stocks between residential turf grass and native soil. Urban Ecosystems 12:45-62.

Roach, W., and N. Grimm. 2011. Denitrification mitigates N flux through the stream-floodplain complex of a desert city. Ecological Applications 21:2618-2636.

Roberts, B. J., P. J. Mulholland, and J. N. Houser. 2007. Effects of upland disturbance and instream restoration on hydrodynamics and ammonium uptake in headwater streams. Journal of the North American Benthological Society 26:38-53.

Rosgen, D. L. 1994. A classification of natural rivers. Catena 22:169-199.

Royer, T. V., and M. B. David. 2005. Export of dissolved organic carbon from agricultural streams in Illinois, USA. Aquatic Sciences 67:465-471.

Ryan, R. J., C. Welty, and P. C. Larson. 2010. Variation in surface water-groundwater exchange with land use in an urban stream. Journal of Hydrology 392:1-11.

Ryder, D. S., and W. Miller. 2005. Setting goals and measuring success: linking patterns and processes in stream restoration. Hydrobiologia 552:147-158.

SAS Institute. 2003. SAS Analyst. Version 9.1. SAS Institute, Cary, North Carolina, USA.

Schaller, J. L., T. V. Royer, M. B. David, and J. L. Tank. 2004. Denitrification associated with plants and sediments in an agricultural stream. Journal of the North American Benthological Society 23:667-676. 
Sickman, J. O., M. J. Zanoli, and H. L. Mann. 2007. Effects of urbanization on organic carbon loads in the Sacramento River, California. Water Resources Research 43:W11422.

Sivirichi, G. M., S. S. Kaushal, P. M. Mayer, C. Welty, K. T. Belt, T. A. Newcomer, K. D. Newcomb, and M. M. Grese. 2011. Longitudinal variability in streamwater chemistry and carbon and nitrogen fluxes in restored and degraded urban stream networks. Journal of Environmental Monitoring 13:288-303.

Smith, M. S., and J. M. Tiedje. 1979. Phases of denitrification following oxygen depletion in soil. Soil Biology and Biochemistry 11:261-267.

Sobczak, W. V., S. E. G. Findlay, and S. Dye. 2003. Relationships between DOC bioavailability and nitrate removal in an upland stream: An experimental approach. Biogeochemistry 62:309-327.

Striz, E. A., and P. M. Mayer. 2008. Assessment of near-stream ground water-surface water interaction (GSI) of a degraded stream before restoration. EPA 600/R-07/058. U.S. Environmental Protection Agency, Office of Research and Development, National Risk Management Research Laboratory, Ada, Oklahoma, USA.

Taylor, P. G., and A. R. Townsend. 2010. Stoichiometric control of organic carbon-nitrate relationships from soils to the sea. Nature 464:1178-1181.

Ulseth, A. J., and A. E. Hershey. 2005. Natural abundances of stable isotopes trace anthropogenic $\mathrm{N}$ and $\mathrm{C}$ in an urban stream. Journal of the North American Benthological Society 24:270-289.

U.S. EPA [Environmental Protection Agency]. 1993. Process Design Manual for Nitrogen Removal. EPA 625/R-93010. U.S. EPA, Cincinnati, Ohio, USA.
U.S. EPA [Environmental Protection Agency]. 2006. Baltimore County stream restoration improves quality of life. EPA/903/ F-06/008. U.S. EPA, Mid-Atlantic Integrated Assessment, Fort Meade, Maryland, USA.

U.S. EPA [Environmental Protection Agency]. 2011. Section 319 nonpoint program success story; restoring stream improves water quality and fish community health. EPA 841-F-11-001G. U.S. EPA, Washington, D.C., USA.

Vannote, R. L., G. W. Minshall, K. W. Cummins, J. R. Sedell, and C. E. Cushing. 1980. The river continuum concept. Canadian Journal of Fisheries and Aquatic Sciences 37:130 137.

Warrner, T. J., T. V. Royer, J. L. Tank, N. A. Griffiths, E. J. Rosi-Marshall, and M. R. Whiles. 2009. Dissolved organic carbon in streams from artificially drained and intensively farmed watersheds in Indiana, USA. Biogeochemistry 95:295-307.

Waterson, E. J., and E. A. Canuel. 2008. Sources of sedimentary organic matter in the Mississippi River and adjacent Gulf of Mexico as revealed by lipid biomarker and $\delta^{13} \mathrm{C}$ TOC analyses. Organic Geochemistry 39:422-439.

Wiegner, T. N., and S. P. Seitzinger. 2004. Seasonal bioavailability of dissolved organic carbon and nitrogen from pristine and polluted freshwater wetlands. Limnology and Oceanography 49:1703-1712.

Wiley, M., L. Osborne, and R. Larimore. 1990. Longitudinal structure of an agricultural prairie river system and its relationship to current stream ecosystem theory. Canadian Journal of Fisheries and Aquatic Sciences 47:373-384.

Yesilonis, I. D., B. R. James, R. V. Pouyat, and B. Momen. 2008. Lead forms in urban turfgrass and forest soils as related to organic matter content and $\mathrm{pH}$. Environmental Monitoring and Assessment 146:1-17.

\section{Supplemental Material}

\section{Appendix A}

Table of studies from a broad range of land uses and contexts that examine how different organic carbon sources affect denitrification rates (Ecological Archives M082-016-A1).

\section{Appendix B}

Aerial photographs of sampling locations at the forested Pond Branch and Baisman Run, the restored Minebank Run and Spring Branch, and the unrestored urban Scotts Level Branch and Dead Run streams (Ecological Archives M082-016-A2).

\section{Data Availability}

Data associated with this paper have been deposited in Dryad: http://dx.doi.org/10.5061/dryad.4gk00 